Portland State University

PDXScholar

5-3-1995

\title{
Authorizing the Reader: Narrative Construction in Sarah Orne Jewett's The Country of the Pointed Firs and Willa Cather's My Antonia
}

Cheri Buck-Perry

Portland State University

Follow this and additional works at: https://pdxscholar.library.pdx.edu/open_access_etds

Part of the English Language and Literature Commons

Let us know how access to this document benefits you.

\section{Recommended Citation}

Buck-Perry, Cheri, "Authorizing the Reader: Narrative Construction in Sarah Orne Jewett's The Country of the Pointed Firs and Willa Cather's My Antonia" (1995). Dissertations and Theses. Paper 4872.

https://doi.org/10.15760/etd. 6748

This Thesis is brought to you for free and open access. It has been accepted for inclusion in Dissertations and Theses by an authorized administrator of PDXScholar. Please contact us if we can make this document more accessible: pdxscholar@pdx.edu. 


\section{THESIS APPROVAL}

The abstract and thesis of Cheri Buck-Perry for the Master of Arts in English were presented May 3, 1995, and accepted by the thesis committee and the department.

COMMITTEE APPROVALS:

Nancy Porter

Chair

Sherrie Gradin

Christine Rose

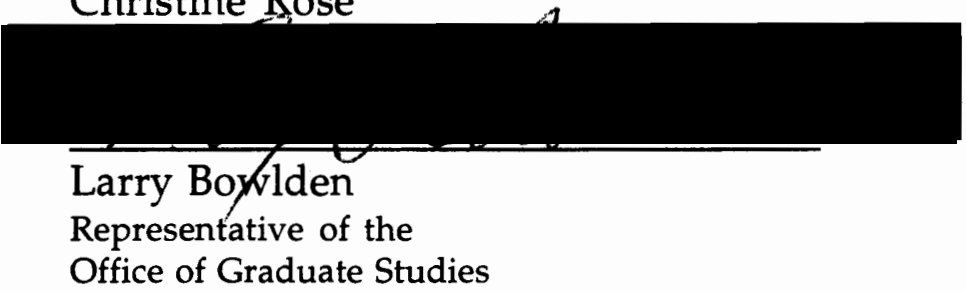

DEPARTMENT APPROVAL:

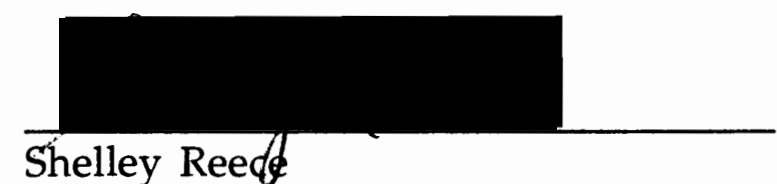

Chair, Department of English

ACCEPTED FOR PORTLAND STATE UNIVERSITY BY THE LIBRARY

by

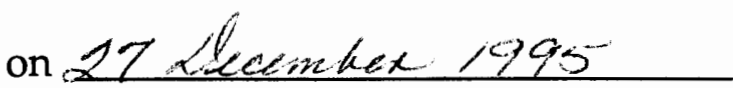




\begin{abstract}
An abstract of the thesis of Cheri Buck-Perry for the Master of Arts in English presented May 3, 1995.
\end{abstract}

TITLE: Authorizing the Reader: Narrative Construction in Sarah Orne Jewett's The Country of the Pointed Firs and Willa Cather's My Ántonia.

Although Willa Cather's My Ántonia and Sarah Orne Jewett's The Country of the Pointed Firs have been highly regarded by numerous literary critics, neither text conforms to conventional expectations for narrative content or structure. Episodic in construction, the novels lack such traditional narrative ingredients as conflict, action, drama, and romance. Furthermore, explicit connections between episodes and stories related within the narratives are not drawn for the reader.

Formalist and structuralist critics have approached the problem of structure in Cather and Jewett's works by employing conventional literary tools of analysis, by "unearthing" the narrative elements that we as readers and critics have come to expect: identifiable structure, a plot complete with conflict and resolution, and characters that develop. Likewise, many feminist critics have sought to uncover in Cather and Jewett's work the ideal elements for a woman's text such as the employment of a feminine method of writing. Unfortunately, both approaches utilize interpretive templates that would pin down meaning and thus "solve" the texts" seeming peculiarities. 
Instead of prescribing structure according to accepted conventions or ideals, this study attempts to describe the narrative construction of $M y$ Ántonia and The Country of the Pointed Firs. I argue that these texts are not structured in a traditional linear fashion, but rather are "conversations" among a variety of "readers" - the narrator, other characters, and the actual readers of the text-who attempt to construct an understanding of the world around them, or the meaning of the overall story. The chapters in this thesis explore this dialogue present in Cather and Jewett's work; the various voices participating, as well as their proposed constructions.

Both Cather and Jewett, through their innovative narrative techniques, dramatize the human need to make sense of life, our capacity to create meaning, and at the same time the fallibility of such constructions. By employing a form which resists conventional strategies of explanation, Cather and Jewett encourage an interpretative approach that favors cumulative readings, a certain responsiveness, and an allowance for indeterminacy. 


\section{Authorizing the Reader: \\ Narrative Construction in Sarah Orne Jewett's \\ The Country of the Pointed Firs \\ and \\ Willa Cather's My Ántonia}

by

Cheri Buck-Perry

A thesis submitted in partial fulfillment of the requirements for the degree of

\section{MASTER OF ARTS \\ in \\ ENGLISH}

Portland State University

1995 
Many thanks are due foremost to Nancy Porter who patiently read the following pages and offered her invaluable advice on my circuitous prose. Without her time, energy, and encouragement this thesis project would have been much more difficult to complete and the results not nearly as satisfying.

I owe my gratitude to those fellow graduate students who traveled the thesis path alongside me: Debra Galhoff and Maggie Boettcher. Our weekly meetings with Marcia Silver, who so generously donated her time to us, were a great source of encouragement.

Thanks are also due to Peter Carafiol, for his input in the early phases of this project, and to Christine Rose and Sherrie Gradin, who carefully read the following chapters and offered valuable feedback. 


\section{Critical Contexts}

Joining the critical conversation on Willa Cather and Sarah Orne Jewett means squeezing into an already crowded and contested space. In recent years, scholarship on these authors has grown significantly, largely due to a wave of feminist interest which has furthered the inquiry into the fiction of Cather and Jewett and has helped bring their work into the academic spotlight. One of the most problematic issues for literary scholars concerned with Jewett and Cather is the unusual construction of their most popular novels, The Country of the Pointed Firs and My Antonia. Although both have been highly regarded by numerous critics, neither conforms to conventional expectations for narrative content or structure. Episodic in construction, the novels lack such traditional narrative ingredients as conflict, action, drama, and romance; furthermore, explicit connections between episodes and stories related within the narratives are not drawn for the reader.

Jewett's The Country of the Pointed Firs records the story of an unnamed narrator's visits to Dunnet Landing, a New England coastal village. In each section of the work the narrator relates a new experience in the daily life of the village inhabitants, an existence in which she shares-picking herbs with her landlady and friend Mrs. Todd, listening to the stories of a retired sea captain, eating a supper of fish chowder with her friends the Blacketts, and joining in a family reunion with the Bowden clan. Cather's novel, My Ántonia, follows a similar episodic pattern. At the center of the 
narrative is Ántonia, an immigrant girl struggling to survive with her family on the Nebraskan frontier. Ántonia's story-from her first winter on the prairie, to her father's suicide, to the unfortunate affair with a railroad clerk, to her later successful marriage and family-is told section by section through the perspective of a middle-aged narrator Jim Burden, whose friendship with Ántonia has continued throughout their lives. Neither text is traditionally plotted - many of the stories related by the narrators and other characters don't readily appear to further the action of the novels, and the larger fabric of meaning created by the events and stories in the narratives is left for the reader to create.

Generally speaking, in discussions of the Firs and My Ántonia, formalist and structural critics, such as Warner Berthoff, David Daiches, and E.K. Brown, attempt to deal with the fundamental issues of structure and character by employing conventional literary tools of analysis, or in other words, by unearthing narrative elements that we as readers and critics have come to expect: identifiable structure with a beginning, middle, and end; a plot complete with action and conflict that will be resolved by the end of the book; and characters that develop and learn through the story. These critics have constructed detailed arguments, by carefully "excavating" the texts' respective structure and plot. Unfortunately, these tools often become abstractions or ideal notions prescriptions for the text, what Richard Millington calls a "disembodied Platonic ideal of a book," and have rendered critics unable to see innovative techniques employed by Cather and Jewett (Millington 1). Many feminist critics, in response to the limitations inherent in earlier critical viewpoints, have sought to redefine concepts such as structure and plot in order to see Cather and Jewett's texts in a new light, and 
to explore how they exhibit a different method of writing, possibly a "feminine" approach. However, some feminist critics, such as Judith Fetterly, Deborah Lambert, and Elizabeth Ammons, can be seen as becoming entangled in the same limitations as formalist critics. These feminist scholars have formed their own "Platonic ideal" of a women's text and have come to expect yet another set of narrative elements within a literary work, including: affirmation of women's individuality and freedom, the employment of a feminine method of writing, and evidence of female culture. ${ }^{1}$

In the following pages, I hope to further the discussion of Cather's and Jewett's narrative techniques by offering a different description of the construction of My Ántonia and The Country of the Pointed Firs, based on an understanding of the novel as "dialogic." 2 Like many recent feminists, I see Cather and Jewett as having developed an innovative method of telling stories, possibly a way of relating experience that might be labeled as uniquely feminine. Unlike other feminist and formalist approaches to date, however, the discussion in the ensuing chapters also assumes that the novel as a genre is fluid, open-ended, and without set conventions-a literary form that is self-critical and therefore constantly reinventing itself. Seeing the form of the novel as dialogic suggests a way of reading Cather and Jewett's work that avoids what for me is unsatisfying in the approaches of the formalist and feminist critics briefly mentioned above, namely, the use of interpretative templates that would pin down meaning, prescribe structure according to accepted conventions or ideals, and thus "solve" the texts' seeming peculiarities.

I would argue that My Antonia and the Firs are "conversations," if you will, among a variety of "readers"-the narrator, other characters, and the 
actual readers of the text-who attempt to construct an understanding of the world around them, or the meaning of the overall story. Cather and Jewett chose to structure their works not by plots that build step-by-step in a linear fashion, but rather through the voices and connections made by their narrators and other story-telling characters. Both authors thus provide "narrative glue" for their texts by creating narrators who are fluent in the art of interpretation. And, even more important than the structural role played by the narrator and the other characters is the part that we as readers are encouraged to fulfill. Both Cather and Jewett utilize numerous strategies that invite reader participation, and in many instances, the narratives rely on reader interpretation for overall construction of the story.

While many of the techniques will be further explored and illustrated in coming chapters, I will briefly outline here the methods of narrative construction which invite, and at times require, reader participation. Both authors provide the example of a narrator who actively interprets his or her experiences, and similarly both Cather and Jewett engage other character's voices in relating the overall story. As a result, the narrative burden of relating the story in its entirety is borne by more than one character, as the embedded narratives, the stories set within the larger text, illustrate. Cather, in particular, takes pains to distance herself from the narrator of My Ántonia, thus denying "authorial" authority to his interpretations. Readers are therefore subtly invited to join in the activity of story making, to fashion their own version of narratives and events. Furthermore, Cather and Jewett do net pen exhaustive descriptions of situations and characters, but rather select only a few details leaving the rest of the picture to be filled in by the reader's imagination. And finally, neither author explicitly clarifies the 
relationships between episodes, narratives, chapters, and books. As readers we are often left on our own, with only the narrator's interpretive example as a guide, to creatively fill in the gaps between time lapses, or the relationships between events and stories.

The following pages of this chapter will provide a brief critical context for my description of the way Cather and Jewett's texts are constructed. The coming sections will highlight some of the most important formalist and feminist critical viewpoints to date-voices that have proved the most influential in how we have previously read and understood The Country of the Pointed Firs and My Antonia.

\section{SARAH ORNE JEWETT}

Since its publication in 1896, Sarah Orne Jewett's The Country of the Pointed Firs has elicited an array of responses from critics, illustrating the problematic and puzzling nature of the text. Early reviews praised Jewett for her sympathetic portrayal of Maine country life, some of which described her ability to draw characters as "perfect artistry." And yet others called attention to what they saw a serious flaw in the piece-Jewett's work was "slight on plot." One reviewer remarked: "a good book was never made of slighter material" (Ammons 84).

The Firs does present curious challenges for readers and critics, for although the world it portrays is warmly coherent, the means by which this tight fictional world is constructed is highly unexpected. The narrative 
simply consists of an unnamed, androgynous narrator who visits the Maine coastal village of Dunnet Landing. The narrator interacts with many of the town's inhabitants and writes down her encounters and experiences while in the community. Clearly, the Firs doesn't "do" what novels are expected to "do:" there is no apparent goal to the narrative, no crisis, no suspense, no climax, no resolution, no story line that we can sum up at the end. Jewett herself referred to the parts of the work as "sketches" instead of chapters, implying an open-endedness, a sense that the episodes could stand on their own, rather than units that fit together in a specific order to build a solid, complete story. The narration alternates between third and first person, and the main character, the narrator, whom one would normally think of as a protagonist, can hardly be said to fit the description: she dsesn't overtly propel the story but rather is more like a curious passer-by. The narrator doesn't really act, but rather asks questions, interviews, speculates, and draws connections. And finally, it is difficult to articulate how the characters in the work have developed, if at all.

What one does find in Jewett's Firs, are only the non-events of day-today life: conversations, visits, storytelling, shared meals, the making and maintaining of friendships; and alternatively, worries, separation, loss, pain, loneliness, insecurity, the collapse of the economic viability of the community.

Scholars have attempted to account for the seeming peculiarities in Jewett's work by either dismissing it as an inferior work, and thus relegating it to the category of regionalism, or by relying on the assumption that a "great" work of art must consist of certain elements, therefore, Jewett's text by extension must have those as well. Throughout the critical history of the 
Firs, critics have assumed that the Jewett's text does employ conventional narrative tools including structure, progressive plot and character development. For example, the critics Hyatt Waggoner and Warner Bertoff see in Jewett's text an identifiable linear structure based upon two opposing themes. ${ }^{4}$ However, their critical opinions differ widely on exactly which themes hold the work together illustrating the complexity and difficulty of isolating only two dominate elements that solely provide for structural unity. In "The Art of Jewett's Pointed Firs," Bertoff argues that "the principle ordering device" is not "complicated or esoteric," and supports this statement by a step-by-step tour through Jewett's chapters, noting what he sees as two themes present-that of life countered by principles of death and time. Waggoner, in his article "The Unity of The Country of the Pointed Firs," likewise argues that "the sketches are ordered, they "develop" through a "symbolic pattern" in the text of theme and countertheme-faith, hope, love; as opposed to frustration, loneliness and bereavement. At the end of his article, however, Waggoner realizes the difficulty of explaining Jewett's text with conventional terms: "even after one has noted some such a symbolic pattern as I have just outlined, it remains extraordinarily difficult to state the theme" (Waggoner 73).

More recent critics who similarly attempt to account for the coherency of Jewett's text by overlaying traditional criteria include Patricia Durso and Richard Carson. ${ }^{5}$ For these scholars, the unification of the text is achieved through the progressive development of the narrator. Durso's 1990 study charts the narrator's development chapter by chapter and adds that readers might benefit from the metaphor of the pointed firs, for they are "index fingers" to the narrator's growth in "learning . . . wisdom and insight." 
Along similar lines, Carson's 1983 article, "Nature and the Circles of Initiation in The Country of the Pointed Firs," outlines the "five distinct circular enclosures which the narrator, carefully guided, must pass through to reach the 'secret center' she desires to transcend" (Carson 154).

Sivagami Subbaraman's more recent "Rites of Passage: Narratorial Plurality as Structure in Jewett's The Country of the Pointed Firs," provides yet another, more complex argument. Subbaraman attempts to chart the connection between the main narrative and the series of "embedded narratives;" a connection that proves difficult, he notes, for either those critics such as Bertoff who argue for unity of the text based on the linear thematic sequencing between the episodes, or on the maturation of the narrator, as outlined in the articles of Durso and Carson. Subbaraman argues that the "embedded narratives" (those stories related by other characters) serve two main functions in the piece. First, they mirror the narrator's changes in perspective and perception as she "moves from the affectional realm of women' into open waters" (Subbaraman 62). According to Subbaraman, the narrator moves step by step through "rites of passage" into the "world of women" and then proceeds away from it towards the "ocean." Secondly, for Subbaraman, the other stories told by the characters in the work are actually a "splitting of the main voice" which shifts the narratorial burden, allowing for several narratives and forcing us to "reconstruct the narrative through a series of discourse levels" (62).

Critical to all the above interpretations, from Bertoff's 1959 study to Durso's 1990 article, is the assumption that Jewett's text does conforms to conventional expectations of narrative fiction: the Fir's protagonist is shown to develop, the themes build in a linear fashion, the narrative does have a 
goal, the text is seen as unified structurally. None, except Subbaraman, consider Jewett's possible innovations in form or plot. For the formalist and structuralist critics mentioned above, structural coherence is understood as a progressive system of ordering, a successive process of building towards a climax of conflict and resolution, a linear method by which a foundation is laid before the walls are framed and the roof finished, so to speak. However, "structure," as used by these critics, with its overtones of linear progression and systematic ordering, proves particularly ill-fit for describing the workings of Jewett's text. As mentioned earlier, the critic Waggoner recognizes the limitations of his approach. These critical readings which rely on a progressive understanding of structure consequently prove to be simplistic, and lead to pat and simple explanations that are ironically vague. Carson, for example, never clearly defines the "secret center," nor does Subbaraman clearly explain what the narrator is exactly moving toward, nor can Durso elaborate on the kind of insight or wisdom the narrator gains. ${ }^{6}$

Feminist scholars began to add their voices to the critical conversation in the early 1980 's in order to provide alternative interpretations to the problematic readings of formalist and structuralist critics. Elizabeth Ammons approaches the issue of textual coherence by questioning the basis of our conventional assumptions about written narratives. Ammons, in her article "Going in Circles: The Female Geography of Jewett's The Country of the Pointed Firs," argues that Jewett's self-described lack of skill at plot as "no loss at all" because it allowed Jewett to deviate from stock dramatic architecture and to create a form that was closer to "female relational reality," which is structured "around two essentially female psychic patterns: one of web, the other of descent" (Ammons 83). Ammons grounds her view of Jewett's form 
in a psychological model of sexual difference proposed by Carol Gilligan. For Ammons then, Jewett's text does not move along a conventional linear path, an approach that is attributed to a "masculine" view of reality, but rather the textual form is circular in nature; the work is "nuclear; the narrative moves out from one base to a given point and back again ... and so forth like arteries on a spider's web ... it collects weight in the middle" (85). Ammons believes that "Jewett's separate narrative units do not lead inexorably one to the next. They could be scrambled ... and the book would not disintegrate" (87). Ammons qualifies this statement however, positing that the novel's episodes are not "aimless," but rather are held together by a variety of patterns she sketches such as the friendship between the narrator and Mrs. Todd and the oscillation between "joyful and sorrowful episodes."

Ammons, it seems to me, makes several strides in her study. First, she questions our conventional expectations of fiction in terms of plot and structure, and essentially calls for a "re-vision" of works that are not traditionally plotted. Second, she uses fresh vocabulary for talking about Jewett's unconventional structure. Finally, the implications of Ammon's argument, although not discussed in her article, are perhaps the most significant. If the textual form is circular in nature, and the sketches could be scrambled without the entire fabric of the narrative disintegrating, does this not imply a significant difference in how a reader comes to understand, or "know" by reading fiction such as Jewett's? Ammons then, not only questions expectations of conventional forms, but also implicitly the methods by which readers come to understand a text.

However, Ammon's discussion, like the earlier arguments, remains problematic. Her model of the narrative structure of the work, as mentioned 
earlier, depends on the Gilliganesque assumption that men and women construct reality in different ways. While such significant gender differences may or may not be true, it is difficult to rigidly apply such a model to the construction of narratives, particularly ones like Jewett and Cather's that use female narrators to tell men's stories, and vice versa. ${ }^{7}$ Additionally, Ammon's metaphor of the web, while extremely helpful, presents only a two dimensional model, and thus limits the very complexity that she is trying to account for. Certain themes, ideas, and notions, according to Ammons, are only connectable through the medium of the narrator within the text, failing to take into account the "third dimension"-the connections that we as readers may wish to construct. ${ }^{8}$

The best possible reading, I would argue, is one that acknowledges the role of the "readers" within and outside of the text. In "'Tact is a Kind of Mind-Reading' Empathic Style in Sarah Orne Jewett's The Country of the Pointed Firs," Marcia McClintock Folsom argues a similar position. In delineating what she sees as the "mind-readers" of Jewett's work, Folsom perceptively argues that the technique that enables Jewett's writing to "offer so convincing a celebration of the coherence of the world, and yet to avoid treating it condescendingly" is that of "empathic style." Such a style is characterized by many of the characters' capacity to anticipate one another person's feelings and thoughts. 


\section{WILLA CATHER}

Although Willa Cather's fiction has cumulatively received much more critical attention than Jewett's, the debate over her most popular work, My Ántonia, follows a surprisingly similar line to that of the conversation surrounding the Pointed Firs. Similar to the "peculiarities" in Jewett's text which make description difficult, the workings of Cather's My Ántonia have eluded a satisfactory explanation.

Although the novel has become popular reading (in high schools at least) in part because it moves readers, for critics, the story doesn't conform to traditional expectations for narrative construction. Critics note that despite a structured appearance, for Cather has divided the novel into five books, $M y$ Ántonia is comprised of a collection of episodes that rarely last beyond the length of an anecdote, and many of the stories don't readily appear to further the action of the story. Formalist critics writing in the 1950's, such as David Daiches and E.K. Brown, argue that the text is significantly compromised because it contains "episodes ... that have little if any relation to the story of Ántonia's development," or charge that the novel is simply a "gallery of pictures ... hung in episodical fashion" (Daiches 9, Brown 205). For other critics, the presence of the male narrator Jim Burden is excessive, threatening to eclipse Ántonia's story over the course of the text. Writing in the 1970's, William Stuckey argues that Cather's choice to use a male narrator is not only a technical failure, but a failure of "sensibility." Stuckey calls Jim Burden a "clumsy device the reader must see around" and even more emphatically, Stuckey cringes at Cather's choice to "use him in the first place" and keep on "using him even when it must have been apparent that he was not working" (Stuckey 103). For more recent critics the male narrator has also been seen as 
problematic, as well as what some see as the novel's "many strange flaws and omissions" (Lambert 670). For example, the title of the book leads one to believe that the protagonist of the novel would be Ántonia, but Ántonia herself disappears from almost one entire section of the text. Deborah Lambert, citing the issues of the excessive presence of the male narrator in her 1982 article "The Defeat of the Hero: Autonomy and Sexuality in My Antonia," argues that the novel's "defensive narrative structure" and "the absence of thematic and structural unity" are a result of anxiety and strain that "women writers have endured and to which many besides Cather have succumbed" (690).

As briefly outlined above, some formalist critics have approached $M y$ Ántonia by measuring it against the conventional understanding of structure and plot, and consequently dismiss it on grounds that it fails to live up to these ideal standards, as shown in the arguments of Stuckey and Daiches. Other critics, in an approach similar to that used by some Jewett scholars, go on to assume that those certain ideal elements must be present within a "great" narrative, and attempt to make clear what is not immediately evident. These critics set out to locate the assumed structural coherence, for example, with what might be seen ultimately as abstractions or literary templates such as "nature," "time," "cycles," "pastoral," or "epic."9

Mary Kempter Sternshein and Shelley Saposnik-Noire, for example, illustrate the critical view that sees the shape of the book as determined by the patterns of time throughout the work-the cycle of seasons, the cycle of human life, or the cycle of successive civilizations. ${ }^{10}$ Saposnik-Noire argues "the repetitive theme of birth and death and rebirth as reflected in the prairie landscape imagery provides a unifying link which is the basis for the organic 
structure of the book" (Saposnik-Noire 174). Sternshein goes so far as to argue that the earth and its cycles used by Cather are as important as any of the characters in the novel and "parallel the growth and development of Ántonia" (Sternshein 114). For Sternshein, viewing nature as she does allows for the end of the novel to work as all "good stories" should-by resolving the issues raised over the course of the narrative. She notes that the novel ends after "having securely tied the ends of the story together. Ántonia is finally seen as an earth mother; she and the earth become synonymous with each other" (120).

Instead of turning to the abstraction of nature John Randall uses the concept of romantic allegory as a interpretive tool. Randall deals with the "excessive" presence of the male narrator by viewing Jim and Ántonia as "double protagonists" who "true to the best of traditions of the romantic movement stand for the head and heart ... Together he and the friend of his youth make a complete personality" (Randall 67). Randall likewise argues that "Ántonia's great achievement and the chief subject of the book is the founding of a family" (66).11

Feminist critics writing in the 1980's, however, have dramatically altered the debate on Cather's fiction. As feminist scholars of Jewett's The Country of the Pointed Firs questioned the traditional notion of structure as a linear development in time for example, so critics in interpreting Cather have re-envisioned Ántonia's stature as an "earth goddess" and her rearing of a family. Instead of seeing Ántonia's large family as a positive portrayaì, some feminists critics argue that Cather has helped to perpetuate demeaning stereotypes of women by grounding her female protagonist in the conventional roles of wife and mother. 
Two such dissenting voices raised in the 1980's are those of Judith Fetterly and Deborah Lambert who develop similar arguments, and in large part, base their views on Sharon O'Brien's scholarship concerning Cather's sexual orientation. ${ }^{12}$ Lambert and Fetterly use a markedly different approach from their formalist predecessors by choosing to rely on recently revealed biographical details of Cather's life to reinterpret the significance of the text. Cather's probable lesbianism, and the certain obstacles and anxieties she faced as a woman writer early in the twentieth century, informs their interpretation of her central characters, and on a larger scale, their overall reading of Cather's work.

Lambert, in "The Defeat of a Hero: Autonomy and Sexuality in My Ántonia," argues that after having challenged our conventional expectations in her two early novels with women who take center stage-Alexandra Bergson in O Pioneers! and Thea Kronberg in The Song of the Lark-Cather, in her portrayal of Ántonia, "retreats ... to the depiction of stereotypical patterns" that ultimately "distorts and reduces the lives of women" (Lambert 685-689). Lambert believes that Cather, instead of painting an original character in Ántonia, simply produces "a figure of the greatest conventionality ... the stereotypical earth mother," a role which implicitly denies Ántonia's "individual identity" (687). Cather's use of stereotypical images, according to Lambert, reveals the anxiety Cather felt as a lesbian author, her fear of outwardly expressing her own love, outside the world of fiction, for the real woman from which the character Ántonia was drawn, and her capitulation to conventional expectations as evidenced in her use of Jim Burden as narrator and his espousal of traditional male views of women. ${ }^{13}$ 
Judith Fetterly, in "My Ántonia, Jim Burden and the Dilemma of the Lesbian Writer," makes a similar assessment to Lambert. For Fetterly, the text portrays the "conventional enshrinement of the conventional image of the earth mother" (Fetterly 138). At the heart of Fetterly's argument, also the center of Lambert's, is the assumption that Cather's lesbianism is the determining factor behind the novel; the narrator is simply a "masquerade" for Cather's voice, and yet one that is "radically incomplete" (140). Fetterly finally sees that Cather's real literary achievement lies in her unwillingness to give up her lesbian sensibility, as illustrated by her creation of a "true muse" in Lena Lingard who is perpetually flushed with "luminous rosiness," a sharp contrast to our final glimpse of the battered and flat chested Ántonia. According to Fetterly, Lena is the "source of poetic inspiration," a symbol of the "lesbian self retained against all odds" (145).

More recent critics such as Hermione Lee, however, find Lambert and Fetterly's portrayal of Jim as a "masquerade" for Cather's own ambivalence about her sexuality a limiting interpretation. Lee, in her 1989 article "The Road of Destiny," argues that "to read Jim Burden ... simply as a mask for lesbian feelings is a narrowing exercise" (Lee 167). While Lee agrees that an artist's social environment and their sexual orientation play a significant role in the type of work created, she argues that is very difficult to provide specific textual support for Jim as a façade for same-sex love. According to Lee, Jim is a complicated androgynous narrator that moves comíortably between male and female worlds.

Although the arguments of Lambert and Fetterly thoroughly examine Cather's predicament as a woman writer in the early twentieth-century, a situation not given full attention previously, their assertions contain 
numerous inconsistencies. For example, both argue that Ántonia is an utterly conventional character. However, a close reading of the Cather's work reveals that Ántonia works in the fields alongside men, at times dresses like a man, is the driving force behind a successful farm, bears a child alone without help, and is occasionally shunned by Jim himself because she is not "ladylike." Moreover, Fetterly herself firmly relies on stereotypes for her own argument. Fetterly's argument that Lena Lingard is Cather's "muse" is grounded in the traditional concept of female beauty. Lena is soft, rosy, fleshy-characteristics traditionally associated with feminine beauty. Fetterly affirms this stereotype, setting it up the object to be desired by Cather, thereby transposing to Cather traditional male notions of what is desirable in a female.

The best possible reading of Cather's text, I would argue, is one that takes into account the complex construction of the narrative, particularly Cather's emphasis on the reconstructed, "re-collected" nature of the text. Two recent critical views, posited by Susan Rosowski and David Laird, have moved away from the formalist position of applying literary templates and the strain of the feminist approach using biographical information as a interpretive tool, and point to Cather's innovative narrative techniques. While often relying on Romanticism as template in her book study of Cather The Voyage Perilous: Willa Cather's Romanticism, Rosowski in a smaller article develops a significant insight. In "The Romanticism of My Ántonia: Every Reader's Story," she notes that Cather "has made her narrator an instrument of perception and a maker of meaning, but she has withheld from him the power of making the novel's validity" (70). Rosowski goes on to assert that Cather's text requires each reader to create his or her own story of 
Ántonia. Likewise, David Laird in his 1992 article "Willa Cather's Women: Gender, Place, and Narrativity in O Pioneers! and My Ántonia," argues that Cather has "moved well beyond the familiar paths of traditional narrative" through her construction of a composite portrait of Ántonia. Laird recognizes the distance the author places between her and the presence of the male narrator as a strategy that puts the central narrative and the interpretation's made by Jim into question.

In the following chapters, I will figuatively pick-up where Folsom, Rososki, and Laird leave off in an attempt to explore Cather and Jewett's narrative techniques. Naturally, coming to terms with the "how" of the texts-innovations in form and narrative techniques-has significant implications for our interpretations of the works. Seeing, for example, that Cather's text is composed of a series of constructions, or perspectives, and that the work itself contains an inherent critique of the interpretations made by the narrator leads to a markedly different reading from some of the feminist critics mentioned above. Similarly, viewing Jewett's work as a dialogue between multiple voices provides a very different reading of Jewett's structure than those who propose a linear development, for conversations by nature are not linear but rather cumulative.

My purpose will be to examine the narrative techniques, strategies, and form employed in Cather and Jewett's texts, and to investigate the implications of these strategies in order to help us better understand and interpret the works. Each chapter will explore the dialogue present in Cather 
or Jewett's work; the various voices participating, including the narrator, other characters, and the reader, as well as their proposed constructions. 


\section{CHAPTER TWO \\ Sarah Orne Jewett \\ "Story-writing is always experimental ..." \\ -Jewett}

The edition of The Country of the Pointed Firs that many of us might pick up and read today is significantly different from the text published in book form at the end of the nineteenth-century. Originally serialized in the magazine The Atlantic, the Pointed Firs sketches the experiences of one writer's summer in a small village on the coast of Maine. Beginning with the unnamed narrator's arrival in the community of Dunnet Landing, the story portrays her growing friendships with several of the villagers and the many events of daily life in which she shares, including meals, visits, and family reunions. Jewett herself continued to write stories about the narrator's experiences in Dunnet Landing in a serial fashion, pieces she called "sketches," and added two to the collection before the numerous pieces were assembled and published as a book in 1896. However, with each new edition of the Firs significant alterations were made, revisions that continued almost twenty years after Jewett's death. These alterations naturally mirrored each new editor's understanding of the nature of the work-the novel's structure and plot, or lack thereof-and provided fuel for a long standing debate among literary critics over which text should be the definitive edition.

A few specifics will help outline the critical problem. After Jewett's death in 1909, a new edition of the Firs, copyrighted by Jewett's older sister Mary, went to press with the addition of two sketches which could be seen as disturbing the time-line of the original collection. This new version added 
"A Dunnet Shepherdess" and "William's Wedding," pieces that portray a later visit the narrator makes to the village after her lengthy initial summer stay. Interestingly enough, these sketches were inserted before the final chapter in which the narrator takes her leave at the end of the summer. In 1919, another sketch, namely "The Queen's Twin," was added in the edition published by Houghton Mifflin. And finally, the text was yet again altered six years later in 1925, when Willa Cather in preparing the Mayflower Edition reversed the order of two chapters: "William's Wedding" and "The Queen's Twin." Since then, most book companies have continued without comment to publish the Firs after the fashion of Willa Cather's arrangement, with the three additional sketches inserted between the first twenty chapters and the final chapter, although there is no concrete evidence available to document Jewett's intent to add the separate sketches to the original work. ${ }^{1}$ Apparently, for the 1925 edition, Willa Cather relied solely on her own interpretation and understanding of the work for the re-arrangement of the sketches.

The inevitable scholarly debate over the preferred edition, foregrounds questions central to critical interpretations of the work: What kind of work is it? Does the Pointed Firs have a linear progressive plot that will disintegrate with additions, even though the added sketches focus on the same characters? Does the text have a unified structure that will be dismantled or collapse because of the inserted sketches? ${ }^{2}$ As mentioned in Chapter One of this thesis, numerous scholars in their attempt to illustrate how Jewett's text works have argued for a progressive plot, or a linear movement in character development.

However, I would like to suggest another way of reading the Firs. I would describe Jewett's text as a conversation between many voices: the 
voice of the narrator, the voices of those characters that relate what the critic Subbaraman calls the "embedded narratives," as well as the voice of the reader. I see Jewett's text then, as displaying a type of coherency, but not in the conventional terms: a linear plot consisting of conflict between opposing forces progressively moving towards a climax, followed by a resolution or denouement. Jewett's work, in contrast, shuns conflict, lacks a protagonist, and instead provides an observer who actively reads her surroundings. Jewett's sketches do not inexorably lead from one to the next, rather, the episodes are woven together through the narrator's ability to connect with the town's inhabitants on a literal level by making new friendships, but most importantly through her sophisticated abilities of interpretation. The narrator, as well as several other characters, are acute observers and interpreters who, through their capacity to empathize and envision another character's point of view, draw connections and construct meaning from often only a few simple visible facts. Jewett's characters commonly share the ability to read each other wishes, social situations, the natural world, and most importantly meaning from simple everyday events.

In addition to the example of various characters who often actively interpret their surroundings, Jewett utilizes a variety of narrative strategies that clearly encourages readers of her text to participate in the overall construction of meaning. Such techniques include the absence of overt relationships between episodes in the work; while arranged somewhat chronologically the sketches are not inevitably linked. We as readers are asked to make these links, to creatively envision a larger pattern of meaning.

In the late sketch "William's Wedding," a piece not even fully revised at the time of Jewett's death, Jewett's narrator most fully describes a way of 
reading and responding to the overall collection of sketches through her invitation for us as readers to make "recognitions." Returning to the village months after her initial summer visit, the narrator reflects on the process of recording her experiences in the small community. Here, for really the only time in the entire text, she addresses her readers directly, interestingly enough on the topic of interpretation. She remarks: "It is difficult to report the great events of New England; expression is so slight, and those few words which escape us in moments of deep feeling look but meagre on the printed page. One has to assume too much of the dramatic fervor as one reads" (217). In contemplating the difficulty of the writer in recording life on the printed page, where its black and white words appear so insubstantial to the lived experience, she recognizes that readers must constantly be imagining, assuming, filling in, putting themselves into the experience in order to make the words "come to life." In this one remark, the narrator's concept of communication is one that almost melts the functions of the reader and writer together. In order for communication to take place, for anything close to the actual emotional experience to be related, the reader must make assumptions, interpret the words on the page, envision what the situation must have been like. But later as the narrator is received at breakfast-time by her host, and now good friend Mrs. Todd, she feels "something take possession" of her that "ought to communicate itself to the least sympathetic reader of this cold page. It is written for those who have a Dunnet Landing of their own: who either kindly share this with the writer, or possess another" (217). Clearly, the narrator hopes to connect with readers who are perhaps the most lacking in a capacity fundamental to communication, that of empathy. 
The narrator invites us to make the words she has penned mean something to us.

But not only is an interpretive ability important to communication, such as reading from a printed work, it is also, according to the narrator, a capacity that makes life and its experiences rich and meaningful. The narrator concludes that "the gift to one's life is only in its discernment ... The happiness of life is in its recognitions. It seems that we are not ignorant of these truths, and even that we believe them; but we are so little accustomed to think of them, they are so strange to us" (218). In the above passages, the narrator encourages us as readers of her text to use our ability to recognize patterns, to make connections, to practice a way of seeing and interpreting that combines intellect, curiosity, imagination, and empathy.

In the broadest sense, the plot of Jewett's The Country of the Pointed Firs,-the text's "business" so to speak-is to make connections. On a literal level, much of the happenings that take place in the work are of people coming together, often despite obstacles and difficult circumstances. Every character in Jewett's Pointed Firs, is in some way effected by those natural forces beyond the control of human beings-weather, distance, illness, economic decline, accidents, and death-which keep lovers apart, families and friends separated, and a community in relative isolation. For example, Mrs. Todd, the main figure of the Firs, has lost her husband to the sea, and perhaps even more poignantly, was separated from the only man she loved even before her marriage. Mrs. Todd is also physically separated from her 
beloved mother and brother who live on the remote Green Island. The character Joanna Todd likewise loses the man she loves to another woman, and as a result isolates herself from the rest of her community passing out her days on Shell-heap Island. Similarly, William and his beloved shepherdess are kept apart by family circumstances and physical distance and for most of their courtship only see each other once a year. Even the neighbor Captain Littlepage suffers the loss of his profession as sea captain, and relates a story of loss—of the ship he lost at sea and the explorer whose "discovery" of the northern island of "fog-people" is lost to the rest of mankind. And, the Bowden clan, whom we as readers meet only briefly, are separated by distance from one another, allowing only one gathering a year. The narrator of the Firs notes that the "leave-takings" of the elderly gathered at the Bowden reunion are particularly affecting because they know separation is an inevitable part of life: " . . it is the old who really value such opportunities; as for the young, it is the habit of every day to meet their comrades, 一the time of separation has not come (109).

On a larger scale, the community of Dunnet Landing as a whole suffers from the great loss of the seafaring industry. The effects of the decline in the sea industry is felt by all, for as Captain Littlepage notes, Dunnet Landing grows increasingly isolated from the rest of the world. Mrs. Todd as well as many of the Bowden clan, the narrator observes, are hurt by the lack of vigor from a thriving community: "More than one face among the Bowdens showed that only opportunity and stimulus were lacking,-a narrow set of circumstances had caged a fine able character and held it captive" (107).

However, the forces that would separate the community and individual family and friends are balanced by the important connections 
made between the characters in the piece. Against the forces of space, weather, distance, circumstance, and death, the characters of the novel strive to connect with one another. They come together to visit, share meals, and tell stories. What might be called the "events" or the "drama" in Jewett's piece are the times of coming together: the narrator and Captain Littlepage spend an afternoon in the schoolhouse, Mrs. Todd and the narrator travel to visit the Blacketts on Green Island for an unforgettable visit, Mrs. Fosdick spends time at Mrs. Todd's house swapping "reminiscences," and the Bowden's meet for a reunion. Paradoxically, moments of separation for some also serve to bring others together-the funeral of old Mrs. Begg is just such an occasion, and Joanna, the self-imposed hermit of Shell-Heap Island, becomes an impetus for pilgrimages for her grave site is a "shrine of solitude."

Fittingly enough, the talents and arts that are held in high esteem throughout the piece are those that serve to foster community and connections - the arts of "visiting" and "hosting." Mrs. Fosdick is a noted visitor, the Bowdens make the narrator feel like a family member, and Mrs. Blackett has the amazing ability to make her guest feel right at home. Mrs. Blackett, in fact, keeps a "best room" set aside just for the purpose of coming together-a symbol of community: "It was indeed a tribute to Society to find a room set apart for her behests out there on so apparently neighborless and remote an island." But, the narrator notes, "Mrs. Blackett was of those who do not live to themselves, and who have long since passed the line that divides mere self-concern from a valued share in whatever Society can give and take"(41). These arts of hospitality, of connection, might be properly called "women's arts." Women in the sketches are overwhelmingly 
responsible for the social rituals of tea, making chowder for family and friends, providing healing herbal potions, and emotional balms for the members of the community. In a village whose economy is based upon seafaring, the men are naturally off at sea, or have been claimed by the ocean, and the womenfolk are responsible for the day to day up-keep and the continuance of the community fabric.

In addition to the "business" of the work being the making of connections on a literal level, Jewett's text is structured through the reading and reading patterns of the narrator and several other characters. And finally, the Firs' structure of meaning is likewise completed by those connections that we as readers my wish to construct.

The narrator of the Firs seems to ascribe to an aphorism Jewett herself had tacked up over her secretary in her home in South Berwick, Maine. The aphorism by Flaubert read: "Écrire la vie ordinaire comme on écrit l'histoire." Or, the artist's job is to write ordinary life as if writing history. Jewett's narrator does write as if only to faithfully preserve her experiences, the people she meets and makes friends with, and to record the stories they have to tell. The narrator sets herself up to simply transmit what she sees, hears, and experiences, and as readers, we are never introduced to our "historian." We never learn her name, age, anything about her family, her background; we only are told her occupation-she writes. Although numerous stories are told over the course of the book she never inserts a personal tale of her own, rather, she readily asks questions, curiously 
inquires, and carefully listens. The lack of dramatic personality on the part of the narrator allows for one of the most prominent features of the piece: through this recorder of human experience we hear other voices as well. In faithfully taking down other character's stories, the overall "story" of the Dunnet Landing community is actually told by multiple narrators.

However, the narrator is more than a simple recorder, she is also an interpreter, an expert "reader" who draws connections, fashions meaning, and constructs a larger meaning from the stories, people, and activities she experiences. The narrator's way of seeing could be characterized by her developed capacity for empathy-through careful observation of a few outer facts or details, the narrator is able to envision person's perspective and the surrounding situation. The narrator's interpretive ability serves to collapse barriers that would otherwise keep humans apart; barriers such as personal differences, time, distance, and humanity's perceived separation from the natural world. For example, the narrator repeatedly draws on references of the past to color her portraits of the present and often uses metaphors from the natural world to describe friendship, a human connection.

The chapter "On Shell-heap Island" gives a rich example of the narrator's empathetic and interpretational abilities. The literal action in this brief sketch amounts to almost nothing: the narrator lands on a small island and takes a walk to the few traces left of an island dweller deceased for more than twenty-years. In the previous two chapters the narrator has become aquatinted with this past island inhabitant-"poor Joanna"-through the reminiscences of Mrs. Todd and her visitor Mrs. Fosdick. With the help of the narrator's questions, the two friends slowly recount the story as if sifting through the details for some understanding of Joanna's choices. 
Disappointed in love, Joanna Todd exiled herself to Shell-heap Island to live out the rest of her days in isolation.

Moved by Joanna's troubles and her self-imposed solitude, the narrator follows her impulse while out sailing one day and asks to be let out on the island to visit what's left of the hermitage and grave site. The narrator finds a path that leads to the to grave, and immediately interprets a larger significance for this small detail:

it was touching to discover that this lonely spot was not without its pilgrims. Later generations will know less and less of Joanna herself, but there are paths trodden to the shrines of solitude the world over,the world cannot forget them, try as it may; the feet of the young find them out because of curiosity and dim foreboding; while the old bring hearts full of remembrance (82).

From the worn path the narrator connects the past, present, and future generations of visitors and interprets the impetus behind such pilgrimages to the "shrine of solitude."

As the narrator walks along, birds flutter up from the grass, and she likes to think that even they make a connection between the past and future pilgrims by keeping "some happy tradition from summer to summer of the safety of nests and good fellowship of mankind." As the narrator observes the few remains of Joanna's past home and garden-the stones used for a cottage's foundations and the sprigs of the "much enduring French pink"her mind moves to other people: "I drank at the spring, and thought that now and then some one would follow me from the busy, hard-worked, and simple-thoughted countryside of the mainland, which lay dim and dreamlike in the August haze as Joanna must have watched it many a day" (82). She imaginatively steps into Joanna's shoes when she hears voices and laughter from a pleasure-boat going seaward full of children: "I knew, as if 
she had told me, that poor Joanna must have heard the like on many and many a summer afternoon, and must have welcomed the good cheer in spite of hopelessness" (82).

The narrator's observations, reflections, and her capacity to imagine what Joanna's existence must have been like, create a scene in which time appears to condense. Individuals from the long ago and far into the future are linked together as the narrator looks out across the water: "There was the world, and here was she with eternity well begun" (82). From only a few visible remains the narrator not only imaginatively step's into Joanna's perspective, but draws the anchorite into the larger body of society by reflecting on experiences common to all of humanity: "In the life of each of us, I said to myself, there is a place remote and islanded, and given to endless regret or secret happiness; we are each the uncompanioned hermit and recluse of an hour or day" (82).

Moreover, the scene on Shell-heap Island takes on an added dimension, as we as readers may make the connection between the perspective of Joanna, a person observing from the "outside" of the community, her "pilgrims" in search of a place of solitude, and that of the narrator, likewise an observer of Dunnet Landing. The narrator herself often chooses to be an "outsider," taking pains to stand at a distance in order to gain perspective. The impulse which drives visitors to the island is the same that compels the narrator to come to Dunnet Landing, the need for a detached place from which to take stock of one's own life.

As seen in the sketch of Shell-heap Island, above, the narrator's imaginative and interpretive abilities weave connections between people from the past, present and future. The narrator's keen ability to make 
meaningful links between the past and present adds depth to the most simple of actions. This characteristic of the narrator's overall way of seeing also turns up over and over again in her descriptions of characters and events. For example, the narrator consistently draws on references from the past to add depth to her portraits of the present, giving them a sense of timelessness. Mrs. Todd, for example, "might belong to any age, like an idyll of Theocritus" (59). As the two talk during their expedition to Green Island and come to sit in a pennyroyal patch, Mrs. Todd confesses that the herb always reminded her of her love for a man other than her husband. The narrator here notes that Almira Todd "might have been Antigone alone on the Theban plain" for "an absolute, archaic grief possessed this countrywoman; she seem like a renewal of some historic soul, with her sorrows and the remoteness of a daily life busied with rustic simplicities and the scents of primeval herbs" (49). Likewise, Elijah Tilley, a fisherman that the narrator befriends, is painted along with colleagues as "ancient seafarers" who "was always just as you see 'em now since the memory of man."

And similarly, the narrator's descriptions of the Bowden clan reunion, attended by Mrs. Todd and Mrs. Blackett, are also laden with overtones of the distant past. The reuninn is a :ime when "the altars to patriotism, to friendship, to the ties of kindred, are reared in our familiar fields, then the fires glow, the flames come up as if from the inexhaustible burning heart of the earth; the primal fires break through the granite dust in which our souls are set. Each heart is warm and every face shines with the ancient light" (96). As the large company makes a procession for the shaded spot where the picnic will begin, the narrator feels that 
we might have been a company of ancient Greeks going to celebrate a victory, or to worship the god of harvests ... we were no more a New England family celebrating its own existence and simple progress; we carried the tokens and inheritance of all such households from which this had descended, and were only the latest of our line. We possessed the instincts of a far, forgotten childhood (100).

As the narrator looks round the table she imagines that so "their ancestors may have sat in the great hall of some old French house in the Middle Ages, when battles and sieges and processions and feasts were familiar things" (105).

In addition to her use of the past to help paint the present scenes she experiences the narrator uses figures of speech that draw from the natural world, again demonstrating her connected way of seeing. Natural forces are in one sense humanity's enemy; rough seas and storms have taken many a life from Dunnet Landing. However, the narrator does not view nature and society as dichotomies. Rather, the narrator repeatedly draws on nature to help describe her experiences. For example, she describes the growing relationship between herself and Mrs. Fosdick in this way: "You may speak of a visit's setting in as well as a tide's, and it was impossible ... not to be pleased at the way this visit was setting in; a new impulse and refreshing of the social currents and seldom visited bays of memory appeared to have begun" (59).

The anonymous narrator is not the only one with sophisticated interpretational capabilities, however. Other main characters in the FirsMrs. Todd, Mrs. Blackett, and William Blackett-likewise demonstrate the ability to "read" situations, each other's wishes, and even the natural world, through imagining and anticipating another person's point of view.

The chapters which detail the visit of Mrs. Todd and the narrator to her mother's island home ("Green Island," "Where the Pennyroyal Grew," and 
"The Old Singers") clearly illustrate Mrs. Todd's and Mrs. Blackett's abilities to read situations from only a few facts and signals. On the way to the home of Mrs. Blackett on Green Island, Mrs. Todd from still far off-shore recognizes "a tiny flutter in the doorway," a "signal" that has made its way form "the heart on shore to the heart on the sea." Although the narrator notes that Mrs. Blackett can hardly be seen from so far away, Mrs. Todd interprets from just a few signals her mother's figure, her well being, and knows that she must be making preparations for their arrival. Mrs. Todd remarks: "Look at the chimney, now; she's gone right in an brightened up the fire." And even though the two are "still far at sea," Mrs. Todd also examines the health of her mother's crops: "Mother's late potatoes looks backward; ain't had rain enough so far" (34). Moreover, Mrs. Todd also has also rightly intuited her mother's need for more preparations for her guests and has brought along an onion and hooked a haddock during their voyage to the island.

Mrs. Blackett, similarly, models an empathetic approach to relating with others. Over a dinner of fresh fish chowder made in part with the ingredients Mrs. Todd has brought, the narrator wonders at Mrs. Blackett's gift of hospitality: "Her hospitality was something exquisite; she had the gift which so many women lack, of being able to make themselves and their houses belong entirely to a guests pleasure,-that charming surrender for the moment of themselves and whatever belongs to them, so that they make a part of one's own life that can never be forgotten" (46). The narrator continues to admire Mrs. Blackett's highly developed ability to connect with others, to put herself into another's shoes: "Tact is after all a kind of mindreading, and my hostess held the golden gift. Sympathy is of the mind as well as the heart, and Mrs. Blackett's world and mine were one from the moment 
we met" (46). The narrator values in Mrs. Blackett an attitude of responsiveness and empathy that she herself employs, a method of seeing that serves to weave together the entire text.

Two other scenes provide additional rich examples of the interpretive abilities of the narrator and other fellow "readers"-the dinner at Elijah Tilley's home in the chapter "Along Shore" and the fishing trip with William Blackett in "A Dunnet Shepherdess." An evasive and discouragedlooking person, Tilley is part of an alliance of old fisherman who help each other pull their boats ashore, tend to one another's lobster traps in rough weather, and help clean each other's catch. These "ancient seafarers," survivors of an earlier era of fishing, have an "alliance and understanding between them, so close that it was apparently speechless" (115). The narrator notes that she has often wondered about the "inner life and thought of these self-contained old fishermen" and does get the opportunity to satisfy her curiosity when she happens to meet up with Elijah Tilley who emerges "softly out of his dark fish house, as if it were a burrow." As the two walk along beach, Tilley pays careful attention to his companion, shifting the haddock from one hand to the other in order to not have the fish dirty the narrator's skirt (118). Tilley extends an invitation to the narrator to join him later for a dinner of haddock, and the narrator agrees, observing that "I had suddenly left the forbidding coast and come into the smooth little harbor of friendship" (118).

When the narrator returns to Mr. Tilley's house later that same day for supper, she carefully observes his neatly painted yellow and white house for insights into its inhabitant "since a man's house is really but his larger body, and expresses in a way his nature and character" (119). But the narrator finds 
it a bit too modern for the weathered fisherman: "I should have much sooner believed that the smart young wholesale egg merchant of the Landing was its occupant than Mr. Tilley" (119). The inside of the house also yields more interesting clues, for Tilley proves to be an impeccable housekeeper. All of the furnishings, dishes, household items are kept clean and orderly by the old fisherman as a tribute to his late wife that passed away several years ago. As the two talk about his wife, the narrator begins to imagine what Mrs. Tilley must have been like during the long silences which punctuate the conversation: "I began to see her myself in her home,-a delicate-looking, faded little woman, who leaned upon his rough strength and affectionate heart, who was always watching for his boat out of this very window, and who always opened the door and welcomed him when he came home" (122). But the narrator is not the only one able to imagine what Mrs. Tilley's days must have been like, for Mr. Tilley, has also come to envision their past life through the eyes of his wife: "I expect sh'd watch an' watch an' lose heart awaitin' . . . an' be right there watchin' from the door with somethin 'over her head if 'twas cold, waitin' to hear all about it as I come up the field. Lord, how I think o' all them little things!" (123).

Mr. Tilley gives the narrator a tour of his parlor, the "best room" which has been kept exactly as the late Mrs. Tilley had arranged it. From its contents-an unworn carpet, glass vases with their dusty marsh rosemary and prim bunches of bleached swamp grass-the narrator "could read the history of Mrs. Tilley's best room from its very beginning." The narrator, however, finds this room more sad and empty than the kitchen and remarks that only when one envisions the room's history does it become significant: "it was only when one remembered what patient saving, and what high 
respect for society in the abstract go to such furnishing that the little parlor was interesting at all" (124). The narrator goes on to picture what furnishing it might have been like for the modest couple:

... great day of certain purchases, the woman, the clumsy sea-tanned man in his best clothes, so eager to be pleased, but at ease only when they were safe back in the sail-boat again, going down the bay with their precious freight, and hoarded money all spent an nothing to think of but tiller and sail (124).

This sketch begins in the outdoors, along the sea-shore, and moves indoors into a warm domestic space, and on a figurative level, something similar has taken place for the narrator. She begins by observing Mr. Tilley's rough exterior and his almost mute appearance, and moves to a better understanding of his "inner life" and character. Surprisingly, he is articulate about his own feelings for his late wife and likewise keenly empathetic to what must have been her point of view. Again, from a few outer facts, the narrator, as well as Mr. Tilley, are able to reconstruct another's perspective and also interpret a larger significance.

Another scene which illustrates many of the patterns of reading on the part of the narrator, and the other characters in the work, is the fishing trip the narrator takes with William in the sketch "The Dunnet Shepherdess." One morning William stops by the narrator's "office"-the schoolhouse that she has rented for the summer as a quiet place to write-and invites her to go trouting. The narrator gladly leaves her work behind and the two set off. In her normal fashion the narrator contemplates those around her and she begins to think about William's quiet nature, for William hardly speaks. In fact, the narrator notes the excitement generated by an occasion when he speaks three sentences at once (139). But like Elijah Tilley and his fellow fishermen who communicate at a level different than language, William 
"had a peculiar way of giving silent assent when one spoke, but of answering your unspoken thoughts as if they reached him better than words" (140). Having inherited his mother's golden gift of "mind-reading" William has a capacity to connect on a different level with those around him.

As the narrator settles down to fish in the brook, her empathetic sense tunes into the natural surroundings: "The moment that I began to fish the brook, I had a sense of its emptiness; when my bait first touched the water ... I knew that there was nothing to lie in wait for it" (142). She compares the sense she intuits from the brook to a more familiar context: "It is the same certainty that comes when one knocks at the door of an empty house, a lack of answering consciousness and of possible response; it is quite different if there is any life within" (142).

After William and the narrator finish their lunch the two continue on to the house of Ester, William's beloved, and her mother Mrs. Hight. In a manner now familiar, the narrator's first description of the old woman connects her to the ancient past: "In a large chair facing the window there sat a masterful-looking old woman with the features of a warlike Roman emperor ... Her sceptre was a palm-leaf fan" (148). The two ladies converse the afternoon away allowing for Ester and William to spend plenty of time alone. As the narrator and William prepare to leave, we again see the narrator's keen ability to understand those around her by envisioning their point of view. Ester and the narrator "did not speak much together, but ... understood each other" (155). Ester smiles, a smile the narrator can never forget. "There was all the remembrance of disappointed hopes, the hardships of winter, the loneliness of single-handedness in her look, but I understood, and I love to remember her worn face" (155). Finally, at the end another 
sketch, "William's Wedding," we again see William's ability to communicate without language. The narrator tells us that she and William did not speak, but were able to intuit each other's meaning: "William shook hands with me, and looked me full in the face to be sure I understood how happy he was, and stepping into the boat held out his arms to Esther" (226).

The results of this empathetic way of seeing, as described above, are evident in the friendships the narrator makes over the course of her time in Dunnet Landing. In the first chapter of Jewett's work the narrator establishes a pattern of making acquaintances and friendships which repeats in almost all of the sketches. Upon her arrival in Dunnet Landing, the narrator compares the process of getting to know a village to that of a single human relationship cultivated over time: "When one really knows a village like this and its surroundings, it is like becoming acquainted with a single person. The process of falling in love at first sight is as final as it is swift in such a case, but the growth of true friendship may be a lifelong affair" (2). And, at the core of Jewett's Firs, is the growth of the friendship between Mrs. Todd and the narrator. In contrast to her relationship with William and even Elijah Tilley, the narrator's friendship with Mrs. Todd is one that relies on expression, for Mrs. Todd over the months confides her stories and feelings, those that make her what she is, including the story of her separation from her one love, and the loss of her husband at sea. The narrator comes to "know" Almira Todd through these stories but also through repeated outings and time spent together, by which she comes to see Todd's many sides. Before the pair's 
outing to Green Island the narrator remarks show the process of such a friendship: "I had become well acquainted with Mrs. Todd as landlady, herbgatherer, and rustic philosopher; ... but I was yet to become acquainted with her as mariner" (32). By the end of the narrator's visit their relationship has grown so dear that Mrs. Todd can no longer adequately articulate her feelings toward the narrator, and must rely on a business like tone when the narrator departs. Her parting with the narrator is essentially a silent one: "she shook her head and waved her hand without looking back," but not without communication, for Mrs. Todd gives her house guest a basket filled with meaningful items. The basket itself is one that the narrator admired and in it is a lunch for the journey and the coral pin-a gift from Mrs. Todd's late husband for Joanna.

The friendship that the narrator establishes with Mrs. Todd is just one of many that narrator cultivates over the summer, due in large part to her ability to listen, inquire, and empathize with her new acquaintances. The relationship the narrator begins with Mrs. Fosdick is a good example. While Mrs. Todd puts away the dishes after their supper together, Mrs. Fosdick and the narrator get acquainted: "furnished not only with a subject of conversation, but with a safe refuge in the kitchen in case of incompatibility, Mrs. Fosdick and I sat down, prepared to make the best of each other" (59). Mrs. Fosdick, over the course of the evening relates some of her experiences at sea, part of Joanna's story and through shared conversation the narrator and Mrs. Fosdick quickly become "sincere friends." And, as the notion of the past is significant to the narrator's descriptions of the present, so is the concept of a shared past important to the development of friendships. Mrs. Fosdick remarks that past shared experience is necessary to good 
conversation: " . . it does seem pleasant to talk with an old acquaintance that knows what you know. I see so many of these new folks nowadays, that seem to have neither past nor future. Conversation's got to have some root in the past, or else you've got to explain every remark you make, and it wears a person out" (61). Mrs. Todd agrees, laughing "Yes'm, old friends is always best, 'less you can catch a new one that's fit to make an old one out of" and here the narrator notes that her and Mrs. Todd share an "affectionate glance" (62).

As detailed above, Jewett's text does not employ conventional techniques of narrative construction in the forms of a linear plot or character development, rather, Jewett innovatively holds her text together through patterns of events, and most importantly through a way of seeing, an interpretational approach practiced by the narrator and other characters.

Moreover, we as readers are encouraged to "kindly share" in the experiences with the narrator, to likewise read the text with an approach that privileges careful observation and intellectual curiosity (217). We are encouraged to empathize, to envision the characters and events, and finally to "recognize" a larger fabric of meaning-a pattern of connections between the past, present, and future, individuals and their community, and humanity's relationship to nature. The final chapter "A Backward View" again repeats a pattern of seeing that is analogous to our own situation as readers. In this final sketch, reminiscent of a perspective the narrator experiences from Shell-heap Island, the narrator stands at a distance, another 
method like that of close observation for interpreting larger human significance from available detail. As the narrator leaves Dunnet Landing she sees yet another side to Mrs. Todd: "At such a distance one can feel the large, positive qualities that control a character. Close at hand, Mrs. Todd seemed able and warm-hearted and quite absorbed ... but her distant figure looked matelesss and appealing, with something about it that was strangely selfpossessed and mysterious" (131).

We too as readers stand at a distance from the world of the narrator and Dunnet Landing. As the narrator has become friends with Mrs. Todd through seeing her many sides from both up-close and from far away, and thus accumulating of sense of understanding, so we as readers have come to "know" the text. In a process quite different from a conventional mode of learning, as forwarded by piece of literature with a conventional linear plot where many connections are made for the reader, Jewett's text encourages a cumulative approach to understanding. Knowing and thus discerning is an active process, for the reader must make the connections for him/herself, a process which does, in fact, mirror daily life. Jewett's approach to telling stories illustrates "reality" as a concept that we continually construct. As we draw connections in our own lives in order to create meaning, so must we similarly construct meaning in Jewett's text. 


\begin{abstract}
Willa Cather
"My Ántonia ... is just the other side of the rug, the pattern that is supposed not to count in a story."

- Cather
\end{abstract}

While an editor for McClure's Magazine published in New York, Willa Cather traveled to Boston in 1908 to do research for a series of articles. During her stay, Cather had the great fortune to become acquainted with the sixtyyear-old Sarah Orne Jewett, whose work she greatly admired. Although the two author's friendship lasted only a short time, for Jewett died sixteen months after their intial meeting, Jewett was able to pass on advice that would effectively change the course of Cather's literary career. Jewett advised Cather to quit journalism if she wanted to pursue fiction writing seriously: "Your vivid, exciting companionship in the office must not be your audience, you must find your own quiet center of life, and write from that to the world." Cather later wrote: "One of the few really helpful words I ever heard from an older writer, I had from Sarah Orne Jewett when she said to me: 'Of course, one day you will write about your own country. In the meantime, get all you can. One must know the world so well before one can know the parish'" (Donovan 69). Cather finally did leave journalism after actively pursuing her education of "the world," to write about her own "parish" of Nebraska. As Jewett foretold, Cather did come to write about "her own country"-Cather fittingly dedicated her first pioneer novel, O Pioneers!, to the memory of Sarah Orne Jewett. 
Although Cather's first Nebraska novel was certainly unusual in the early twentieth-century for its choice of subject matter-the central character is a female who successfully creates a farm out of the wild prairie-it is in My Antonia that Cather discards the conventions for constructing narratives and most innovatively retools the machinery of storytelling. In her portrait of Ántonia Shimerda, Cather clearly followed Jewett's adivce: "you can't do it in anybody else's way-you will have to make a way of your own" (Donovan 71). Cather chooses to relate the story of Ántonia, a Bohemian immigrant struggling to carve out a living with her family on the Nebraskan prairie, through the eyes of a male narrator. The story related by the narrator, however, doesn't follow a conventional pattern, or consist of the expected ingredients for a novel; there is no explicit love affair, no drama, no broken hearts, no heroes or heroines, nor do many of the episodes clearly forward the plot. My Ántonia is more aptly described as a series of recollections or photographs-farming folk, with their clothes whipped by the wind, encircling a grave dug into the white wasteland; a sweaty, dust caked young woman plowing thick prairie earth; the Russian immigrant Peter with melon juice dripping form his beard; a plow magnified by the setting sun; the Cuzak children clustered around their mother's photo box.

I would argue that Cather, like Jewett, shuns utilizing a plot that builds step-by-step in a linear fashion. Instead, Cather holds My Ántonia together through techniques similar to the "narrative glue" used by Jewett in The Country of the Pointed Firs. Cather's narrator, Jim Burden, is highly skilled in the arts of connection and interpretation. Like Jewett's narrator, Jim provides us with a system of connections to follow. Jim reads his past experience and Ántonia particularly, with interpretative patterns and 
organizational strategies provided ready-made by a variety of sources, including societal expectations for behavior, cultural definitions of success, and novelistic fiction. Jim turns to these interpretational structures for numerous reasons, not the least of which is the attempt to assert some sort of control or mastery over his life, and to author for himself a purpose for his existence.

Cather sets up this usual construction with the help of a framing narrative-a story to introduce the following story. Jim Burden, a legal consultant for a large railway company, and the unnamed narrator of the introduction, presumably Cather, pass the time away on their journey across the great plains by swapping memories of their childhood. Both grew up in the same small midwestern town, experiencing pioneer life together: the climate, the people, and the conditions. For Jim, many of his most meaningful childhood experiences have come to be intimately associated with one Bohemian girl: "More than any other person we remembered, this girl seemed to mean to us the country" (Cather 2). Occasionally, during his long trips cross-country, Jim has jotted down all the stories and experiences he can remember about this Bohemian girl, now a middle-aged married woman-Ántonia Shimerda-Cuzak.

Months later, the introduction notes, Jim brings his collections of writings about Ántonia to the narrator for her to read. Jim apologetically explains: "I didn't take time to arrange it; I simply wrote down pretty much all that her name recalls to me. I suppose it hasn't any form. It hasn't any title either." To this he writes across the front of the legal portfolio "Ántonia," and then after a moment of reflection adds "My" to the title. 
From the outset then, through Jim's attachment of "my" to the title and his apology for its format, Cather alerts readers to the unusual form of the text, its lack of arrangement, its disorganization. What will follow the introduction, we are meant to infer, doesn't fit the prescription for traditional narratives. The following pages are really only a collection of personal jottings, memories, anecdotes, which have not had the benefit of careful planning, or vigorous revision. In other words, we are told that the true protagonist in the coming pages will be memory itself, or rather interpretation, for Jim's seeing and associating has constructed and molded the shape of the following narrative.

In the introduction Cather also subtly hints at the implications and requirements of the narrative techniques she employs. The episodes to follow the introduction are re-collected by Jim, and Cather takes pains to distance herself from his interpretations. As readers, we are left on our own to contend with her silence and Jim's invariably one-sided perspective, which he himself anticipates as he attaches the word "My" to the title of the Ántonia portfolio. Jim's reading naturally comes ready made with inconsistencies, holes, gaps, contradictions, not seen by himself, and we are therefore asked as readers to provide yet another interpretation, to read between the lines, to look for what remains outside his interpretive template.

Although the novel is loosely structured through Jim's attempts to read his experience, Cather also uses what may be seen as a counter-element to the continual interpretation on the part of the narrator. Cather has filled her work with stories and anecdotes that resist conventional interpretations, or stock readings. These stories, as Richard Millington notes, "defy containment by our customary strategies of explanation" and thus encourage 
a markedly different response from us as readers (Millington 5). The overall "story" of Ántonia, like many of the inset narratives, resists the conventional approach of identifying, classifying, and pinning down meaning, rather it invites cumulative readings, an approach characterized by considering numerous possibilities and a certain responsiveness, an allowance for indeterminacy.

Jim Burden's recollections begin with his memories of the physicality of Nebraska. Arriving on the train from Virginia with Jake Marpole, a hired hand of his family's, the ten-year-old Jim feels as if he has stumbled into a place that can aptly be described as "outside of man's jurisdiction" (Cather 8). Like the Shimerda family who arrive on the prairie from Bohemia at the same time, Jim feels as if the Nebraskan frontier is literally the new world. He first glimpses the new surroundings at night while peering over the side of the wagon rumbling towards his grandparent's farm. Staring into the vast emptiness lit only by far away stars, Jim notes:

There seemed to be nothing to see; no fences, no creeks or trees, no hills or fields. If there was a road, I could not make it out in the faint starlight. There was nothing but land: not a country at all, but the material out of which countries are made (7).

Jim's immediate impressions register the prairie's "nonexistence," its capacity for negation, for invalidating humanity's existence and individual identity: "If we never arrived anywhere, it did not matter. Between that earth and that sky I felt erased, blotted out" (8). 
For Jim and his grandparents the struggle for survival within such an inhospitable context is not quite so immediate as for their neighbors the Shimerdas. The bleak conditions on the agricultural frontier force the immigrant family into almost unbearable circumstances; during their first winter they have to make a home in a cave which seems "no better than a badger hole."

In order to make sense of the new and unfamiliar landscape and conditions, and on a more fundamental level the "obliterating strangeness" of nature against which pioneer families must contend, Jim begins to describe the prairie in ways that he can understand. Jim personifies his surroundings, thereby familiarizing the unknown by connecting it to the knowable. For example, he describes the land as a person or animals constantly in motion: "the whole country seemed, somehow, to be running ... I felt motion in the landscape; in the fresh, easy-blowing morning wind, and in the earth itself, as if the shaggy grass were a sort of loose hide, and underneath it herds of wild buffalo were galloping, galloping" (12-13). Against the spaciousness, the vastness, the inadequacy of humans against the void, Jim and his family adopt other natural species as comrades in survival: "Trees were so rare in that country, and they had to make such a hard fight to grow, that we use to feel anxious about them, and visit them as if they were persons. It must have been the scarcity of detail in that tawny landscape that made detail so precious" (21).

Jim also borrows from fictional forms to assist him in constructing his story, often viewing the people and situations around him in terms of heroic tales like The Life of Jesse James, which he reads on the train to Nebraska. When Otto Fuchs, Grandfather Burden's hired hand, comes to pick up Jake 
and Jim at the train station, Jim marvels at his appearance: "He might have stepped out of the pages of Jesse James." Otto's mustache, facial scars, and disfigured ear fuels Jim's imagination. Jim pictures Otto as "lively and ferocious ... as if he had a history. ... Surely this was the face of a desperado" (7).

Jim's "story-book" readings of people also spill over into the natural world around him. For example, he describes the autumn afternoon light and its effects in terms of biblical grandeur: "The whole prairie was like the bush that burned with fire and was not consumed. That hour always had the exultation of victory, of triumphant ending, like a hero's death-heroes who died young and gloriously" (28). As the cold winter days wear on, Jim compares the Burden's wood-frame house and its kitchen dugout to a "tight little boat in a winter sea." Watching his grandfather and hired hands come and go inside and out, he likens them to "Arctic explorers." After reading The Swiss Family Robinson to his grandmother one cold afternoon, Jim decides that the "Swiss family had no advantages over us in the way of an adventurous life" (44).

In the first book of My Antonia, Jim is not the only one who interprets situations, people, and nature, for Mr. Shimerda, Ántonia's father, likewise attempts to find meaning and purpose for his existence in the white wasteland that surrounds him and his family. In contrast to Jim, Mr. Shimerda has few resources to draw on to help him make sense of the raw frontier experience. Mr. Shimerda, having left behind a culture rich in meaning and friendships in the old world, is now a stranger in a new land, stranded, so to speak, without interpretational structures applicable to the daily struggle for existence. For Mr. Shimerda, the only place that holds 
meaning and thus contentment is the Burden's home. When Mr. Shimerda visits their home during the Christmas season he is overcome at the sight of the Christmas tree, covered with its candles and "coloured figures from Austria [which] stood out clear and full of meaning against the green boughs" (57).

Jim recalls that over supper he notices that Mr. Shimerda "liked to look at us, and that our faces were open books to him. When his deep-seeing eyes rested on me, I felt as if he were looking far ahead into the future for me" (57). Unfortunately, Mr. Shimerda's "deep-seeing" eyes focus almost too clearly, for he can only see the nothingness of the vast void that surrounds him. Mr. Shimerda, a man whose orderly dress and appearance illustrates his strong connections to a structured and sophisticated culture, finds that such structure is completely absent on the frontier. Additionally, Shimerda is handicapped verbally; unable to speak English, he can't communicate with his neighbors. Without friends and interpretational structures to make sense of his experience, Shimerda can not go on living and takes his own life.

Jim's own ability to imagine and respond intuitively is exemplified in his understanding of Mr. Shimerda. Jim instinctively knows why Mr. Shimerda killed himself, and Jim imagines that after his death the old man's "exhausted spirit, so tired of cold and crowding and the struggle with the ever-falling snow" comes to take refuge in the Burden farmhouse. Jim recalls: "it was as if $I$ had let the old man in out of the tormenting winter." As Jim sits alone in the house with Mr. Shimerda's spirit he remembers everything that Ántonia had told him about their life in Bohemia, a life he sees as a legend-like, fairy-tale like existence (66). 
Jim's account of Mr. Shimerda's funeral is one of the most moving scenes in the novel, and illustrates how he occasionally relates episodes and then interprets the event for his readers from a perspective far into the future. Jim conveys the details of the funeral-the grave, a tiny spot in the snow-covered waste, the lowering of the coffin, Grandfather Burden's prayer, and Otto's leading of "Jesus, Lover of my Soul." And here, Jim layers the story with his deepened understanding. Looking back on the scene that took place many years before, Jim lets us know that even after the prairie had been "tamed" by civilization, Mr. Shimerda's grave stands as a testament to the struggle for survival waged by so many men and women. Although Shimerda's grave was dug at the exact spot where country roads would later cross at the survey lines, Jim tells us that the roads instead curve around the plot:

so that the grave, with its tall red grass that was never mowed, was like a little island. I never came upon the place without emotion, and in all that country it was the spot most dear to me. I loved the dim superstition, the propitiatory intent, that had put the grave there; and still more I loved the spirit that could not carry out the sentence-the error from the surveyed lines, the clemency of the soft earth roads along which the home-coming wagons rattled after sunset. Never a tired driver passed the wooden cross, I am sure, without wishing well to the sleeper" (77).

From afar, Jim's interpretation creates a symbol of Shimerda's grave, a spot which exemplifies humanity's struggle with nature and its capacity to acknowledge that struggle and make way for the unknown, the inexplicable.

Book I of My Ántonia not only introduces Jim and the other characters' interpretative responses to the rawness of the frontier experience, it also foregrounds and invites a particular approach to constructing meaning 
through several inset narratives that resist definitive explanations. The numerous stories told in the first section of the novel serve several practical purposes for the characters. The act of story-telling provides entertainment and boosts moral for the "Arctic explorers" isolated during their adventure. Stories also provide a way of sharing experience, a way of making connections with others. Jim tells us that on the bitter cold nights during that first winter in Nebraska, the wolves howling outside would remind Jake and Otto of "wonderful animal stories ... and sometimes Fuchs could be persuaded to talk about the outlaws and desperate characters he had known." Additionally, these inset narratives, which build a rich fabric of shared experience and community, invite a particular interpretive response on the part of the reader. These specific stories question conventional interpretational strategies and our expectations for narratives, and thus encourage a response that will later assist in our interpretation of Ántonia.

A good example of a story that helps to strengthen the friendship of Ántonia and Jim, but also asks us as readers to question conventional expectations for narratives is the story of Jim's "heroic" snake-killing. During a stop-off from a trip to a neighbor's farm for a garden tool, Ántonia and Jim encounter a rattlesnake in a prairie dog town. Jim instinctively strikes at the snake with his spade, crushes its head and eventually succeeds in killing it. Ántonia marvels as Jim's masculinity: "I never knew you was so brave Jim . . . You is just like big mans ...." (32). Ántonia's conventional interpretation of Jim's "act of bravery" changes the terms of their relationship. Her enthusiasm for his achievement fills Jim with pride and causes Ántonia to quit her "supercilious air" when talking with him. Upon their return home he finds Ántonia "standing in the middle of the floor telling the story with a 
great deal of color." However, Jim notes that he later recognizes from subsequent experiences with rattlesnakes that this masculine achievement was really a fallacy, for the snake was old and probably too lazy to put up a good fight. Jim writes that "in reality it was a mock adventure; the game was fixed for me by chance, as it probably was for many a dragon slayer" (34). Although Jim's tale follows a very familiar narrative pattern-man conquering natural danger, allegorically suggesting a greater evil as being conquered, complete with admiring female close at hand-Jim puts the stock reading of the episode into question. Through this story, we as readers are invited to view with skepticism narratives with predetermined endings and their accompanying interpretive glosses. This story seems to bait our impulse to generate interpretation only to not reward it. What it finally "means" remains inconclusive.

Another example of a story that resists conclusive reading is the tale that the Russian immigrant Pavel relates on his deathbed to Mr. Shimerda. The story is a gruesome one in which nature willingly bares her teeth, and like the episode cited above, our conventional strategies of explanation prove strangely inadequate. In their old homeland of Russia, Pavel and Peter were once groomsmen at a friend's wedding in a neighboring village. After the festivities were over, the wedding party began to make its way home through the forest in horse-drawn sledges, but the party is suddenly overtaken by a large pack of voracious wolves. One by one the sledges fall to the chasing wolves, and in a last-ditch effort to lighten the load and outrun the raving animals, Pavel and Peter knock the groom out of the sledge and throw the bride after him. Ironically, the first thing Peter and Pavel notice after their harrowing experience is the tolling of the neighboring church bells calling 
villagers to prayer. After the villagers learn of Peter and Pavel's action, they are thrown out of the community. The pair is ostracized by a society for which survival against nature is codified and animalistic "survival of the fittest" is not condoned. For Ántonia and Jim in particular, the horrible and tragic story of Pavel and Peter "was never at an end," and helps to bring the two friends closer together through sharing the experience: "We did not tell Pavel's secret to anyone, but guarded it jealously-as if the wolves of the Ukraine had gathered that night long ago, and the wedding party been sacrificed, to give us a painful and peculiar pleasure" (41). But for us as readers, the story of Peter and Pavel is one that stymies explanation, there seems to be no conclusive key to its meaning, rather it provokes thought: What separates men from animals? In the battle for survival when and why is it not allowable to act like our fellow species? Are there situations in which one must sacrifice him/herself in order to remain included in society? As the critic Millington suggests, we as readers are invited to interpret such a story not by pinning down meaning, but rather by contemplating the various possibilities (Millington 7).

Throughout the first book, Jim's interpretive methods have included trying to tame the unknown in domestic images, otherwise known as personification, and also the application of fictive structures from adventure novels and legends. But Jim's constructions of meaning, while informed from outside sources, often take the form of what might be described as almost a primitive response to the world around him, as evidenced, for example, by his imaginative response to Mr. Shimerda's soul following his suicide. As Jim's recollections concerning his prairie life and the Shimerda family continue into Book II, Jim's interpretive approaches become layered 
with larger cultural organizational patterns. Jim begins to read his surroundings, and Ántonia particularly, with the help of societal constructions, including what might be called "middle-class respectability."

In Book II, the impetus for "reading" also becomes more complex. The forces of weather, climate, and the land, which require some way of making sense of them in order to cope, continue within a small town existence. Jim notes that: "Winter lies too long in country towns ... On the farm the weather was the great fact, and men's affairs went on underneath it, as the streams creep under the ice. But in Black Hawk the scene of human life was spread out shrunken and pinched, frozen down to the bare stalk" (116). Winter light in a country town "did not beautify-it was the light of truth itself." According to Jim, the wind's bitter song cries "This is reality, whether you like it or not. All those frivolities of summer, the light and shadow, living mask of green that trembled over everything, they were lies, and this is what was underneath. This is the truth" (112). But in addition to the "truth" that nature would have humans believe, that of meaninglessness and death, there is also the "truth" of nature's intersection with humanity-human instinctual behavior, namely sexuality. Both "truths," or forces which society can't explain or control, are plainly avoided through interpretive constructs and behavioral codes. In Book II, Jim begins to read fellow characters and his experiences through societal conventions and codes of behavior, particularly concerning gender. This middle-class ideology prescribes respectable and acceptable careers, social skills, and activities for men and women, and a proper way to behave and court for its young people. Likewise, it provides a proper definition for townspeople and immigrarits; Ántonia and her friends are redefined in Black Hawk as "hired girls." Ironically, Jim accepts these 
social views and conventions and yet does not realize that what makes Ántonia and the other farm girls hired out to Black Hawk families so attractive is their unconventionality, their willingness to break the rules. Jim observes: "The country girls were considered a menace to the social order. Their beauty shone out too boldly against a conventional background" (129).

Jim even criticizes social conventions, but blindly follows them unconscious of the discrepancies within his own outlook. For example, near the end of Book I, as Ántonia and her family struggle in the spring to start their farm, the Burdens becoming increasingly worried or dismayed at Ántonia's behavior. Ántonia works alongside her brother Ambrosch to help her family's farm get underway, and to do so she performs jobs traditionally assigned to males. Ántonia runs her own plow team "shouting to her beasts, sunburned, sweaty, her dress open at the neck, and her throat and chest dustplastered" (81). Jim says that "nowadays Tony could talk of nothing but the prices of things, or how much she could lift and endure. She was too proud of her strength"(81). Jim interprets Ántonia's behavior through the lens of expected norms. Ántonia does not fit the gender mold, however, and continues to persist in her "manly" actions of hard work and allegedly rough manners.

In order to save Ántonia from continuing to behave in a masculine way, Grandmother Burden and the family's neighbors in Black Hawk, the Harlings, hire Ántonia to do accepted women's work of cooking, sewing, and cleaning. Ironically, it is Ántonia's spirit, the same fiery nature which spurs her on to do "man's" work, that makes Ántonia so well liked in both of the residences that employ her. In addition to Ántonia's strength and spirit, her special abilities in the area of story-telling help to make her a favorite among 
the Harling children. Saturday nights at the Harling residence are filled with taffy pulls, games, songs, and Jim notes, many times the children turned to Ántonia to provide them with entertainment: "We all liked Tony's stories. Her voice had a peculiarly engaging quality; it was deep, a little husky and one always heard the breath vibrating behind it. Everything she said seemed to come right out of her heart" (113).

Ultimately Ántonia's spirit, her unwillingness to conform to social codes, places her at odds with the Harling family. Mr. Harling forbids Ántonia to attend the town dances because he is uncomfortable with the men that she has attracted at the dances, and with her reputation for being "free and easy" (130). Ántonia chooses to leave the Harling residence instead of allowing Mr. Harling to regulate her behavior.

Jim, ironically, realizes the deadly "side effects" from strict adherence to proper behavior and appearance, conforming to the expected patternsprudent marriage, solid career, expected family life. After his Grandmother has asked him to promise not to attend the firemen's dances because it is an activity unbecoming for a young man of his class, Jim has few social choices available to him. Wandering the streets of Black Hawk in order to occupy himself, Jim speculates on the lives lived within the houses he passes:

The life that went on in them seemed to me made of evasions and negation ... devices to propitiate the tongue of gossip. This guarded mode of existence was like living under a tyranny. People's speech, their voices, their very glances, became furtive and repressed. Every individual taste, every natural appetite, was bridled by caution (140).

Jim clearly describes the deadening effects of the repressive conventions and the rigid behavioral structures required by this middle-class society, and yet he persists in following its prescriptions. 
However, the presence of the inexplicable that pervades Book I, does occasionally rupture through the neatly painted facade of small town life. Ántonia, for example, in one of her moments of story-telling relates an experience that resonates with her father's death, a narrative similar to those in Book I which invite contemplation rather than a definitive explanation. Ántonia tells of an encounter with a country fellow that took place while she was working out as hired hand at a Norwegian settlement outside of town. The man commits suicide by throwing himself into the threshing machine. Ántonia, puzzled at the man's motive, wonders aloud "Now wasn't that strange? What would anybody want to kill themselves in the summer for? In threshing time, too! It's nice everywhere then" (115). The few articles that the transient leaves behind only make the story more puzzling. The penknife, wishbone, and a poem cut out of a newspaper resemble hieroglyphics, symbols without any known key of interpretation.

Equally as unsettling is the licentious Wick Cutter, the second employer of Ántonia, who is an anomaly to the normally cautious Black Hawk citizens. Wick Cutter's behavior likewise ruptures the fabric of civil life. Ironically so, because Wick Cutter is really an example of purely swallowed and digested middle-class values. He is a successful business man, spouts maxims from Poor Richard's Almanac, contributes regularly to Protestant churches, and fastidiously regulates the care of his house, lawn, and buggy. But all his energies disciplined in the area of appearance find an outlet in another facet of his life. Cutter and his wife argue openly and hostilely around town, and Cutter is known for his sexual escapades with his previous "hired girls." Cutter takes his role as the "upper hand" in gender and sexual matters very seriously, and Jim receives an all too clear taste of 
Cutter's "upper hand" when he agrees to stay over at the house in place of Ántonia while the Cutters are supposedly on vacation. Cutter brutally attacks Jim when he discovers Ántonia's disappearance.

Book II ends with one of the most well-known scenes from $M y$ Ántonia. Jim and the "hired girls" including Ántonia go on a summer picnic outside of Black Hawk. The group spends the day playing games in the sun, swimming in the river, picking berries, and swapping stories. The colors and experiences of the episode are reminiscent of a scene in Book I when Jim basks in the late-summer sun in his grandmother's garden. There is a certain slow pace, a meandering quality, and the scene ends with a sight that many critics have read as one of the central symbols in the book, a plow left standing in a field: "Magnified across the distance by the horizontal light, it stood out against the sun, was exactly contained within the circle of the disk; the handles, the tongue, the share-black against the molten red. There it was, heroic in size, a picture writing on the sun" (156). Again, an immediate reaction on the part of us as readers is to "read" the symbol, but Jim doesn't in this case provide any commentary. The plow is simply described and then the story moves on. The scene suggests an interpretation and yet doesn't offer a particular explanation. In fact, we are invited to hold it within our mind's eye, for Jim in the following book uses this picture as a metaphor for describing the effect of distance on his understanding of the people in his life.

Book III of My Ántonia illustrates a successful narrative technique that Cather comes to employ in her later works, such as The Professor's House. In this 1925 novel, Cather insets the book "Tom Outland's Story" precisely into the middle of the larger narrative concerning Professor St. Peter. Cather prefaces the novel with the quote: "A turquoise set in silver, wasn't it? . . . 
Yes, a turquoise set in dull silver" (Cather ix). The story of Tom Outland, is in fact, a small gem, a turquoise set within the "dull silver" of the surrounding narrative. This inset story provides a sharp contrast (in setting, mood, content, values) to the narrative of St. Peter and his family and comes to function as a commentary on the rest of the story.

Book III of My Ántonia works in a similar way to the narrative embedded within The Professor's House; for its presence influences our reading of the rest of the text. The episodes in Books I, II, IV, and V take place on the remote windswept prairie of the great divide in which the title character, Ántonia, is featured as a prominent figure. The events in this middle section, Book III, take place in the city of Lincoln where Jim attends the university. And, in contrast to the episodes in the surrounding books, the scenes in Book III are set predominately indoors either in Jim's own study, other people's apartments, or in a darkened theater. Furthermore, Ántonia's physical presence fades from view, making way for another figure-Lena Lingard. Book III, in terms of the overall novel isn't a "turquoise set in dull silver," but is rather precisely the opposite. The setting, characters, and experiences provide a distinct contrast to Ántonia and the other past figures and experiences in Jim's life, enlarging their importance in his mind.

Jim's new context and increased educational development at the university provide additional methods through which Jim interprets his experiences, including the "lens" of literature. The enclosed, dark, and confined spaces and experiences of Book III, in contrast to those in the first sections, throw the expansiveness of prairie existence and the pioneers who live their lives on its simple stage into sharp relief. Ántonia and the significant persons of Jim's prairie life grow more important because of his 
shift in perspective. Distance and contrast have simplified their characters and have made their mental images (Jim's interpretations of them, really) more powerful. It is as if the story has moved from the great expansive stage of the prairie to play upon the imaginative stage of Jim's mind:

I knew that I should never be a scholar. I could never lose myself for long among impersonal things. Mental excitement was apt to send me with a rush back to my own naked land and the figures scattered upon it. While I was in the very act of yearning toward the new forms that Cleric brought up before me, my mind plunged away from me ... They stood out strengthened and simplified now, like the image of the plough against the sun. They were all I had for an answer to the new appeal ... they accompanied me through all my new experiences. They were so much alive in me that I scarcely stopped to wonder whether they were alive anywhere else, or how (168).

Ironically, the "new forms" do take hold; Jim comes to use these literary forms to help him understand his past experiences, and they ultimately make the past, and the persons who were part of it, more meaningful for him. For example, after reading the Georgics, Jim's connection of Virgil to his own experiences provides "precious" insights. The phrase "Optima dies ... prima fugit," or "the best days are the first to flee" serves as a revelation to him when he applies it to his own past: "It came over me, as it had never done before, the relation between girls like those and the poetry of Virgil. If there were no girls like them in the world, there would be no poetry. I understood that clearly, for the first time. This revelation seemed to me inestimably precious. I clung to it as if it might suddenly vanish" (173).

As the close indoor settings of Book III provide sharp contrast to Jim's past experiences on the open prairie, thus sharpening the lines of his family and friends there, so does the new predominance of another female character help to highlight the emerging picture of Ántonia. Lena Lingard, the title 
character of Book III, is in most ways the opposite of Ántonia. Lena's behavior and demeanor could be described with many of the qualities normally associated with the feminine. She is soft-spoken, pretty, plump, concerned with her appearance, and comes to make her living through her talent in making other people attractive-Lena becomes a leading dressmaker in Lincoln and later San Francisco. Ántonia, in contrast, is consistently described in the first two books as having "masculine" qualities. Even on the way to the Black Hawk dances, Ántonia "breaks into a run like a man" (132). Ántonia's talents lie in the hard work of farming and as later shown, in raising a large family, something Lena emphatically decides against. Lena is also the darling of men's affections. While on her family's farm she is chased by a fellow neighbor, in Black Hawk the son of the town banker becomes "daft" about her, and in Lincoln her neighbor, landlord, and eventually Jim all fall in love with her.

Many of the episodes in Book III also further illustrate Jim's remarkable ability to imagine, to create, to envision, despite significant obstacles, characteristics he will later draw on in order to throw off conventional interpretational structures prescribed by society to construct his own understanding of the importance and meaning of Ántonia's friendship. Throughout Book III, Jim and Lena attend the Lincoln theater regularly together, and both are greatly moved emotionally by the dramas they see. Jim, despite the inadequacies of the actors and actresses, has the capability to "suspend his disbelief" and imaginatively construct the perfect drama within his own mind's eye. For example, the lead part in the play Camille that the pair attends is cast with an old, infirm actress. Jim tells us that she was even lame, "But what did it matter? ... I believed her young, ardent, reckless, 
disillusioned ... the lines were enough. She had only to utter them. They created the character it spite of her" (177). Jim weeps "unrestrainedly" at the performance of this old decrepit actress, and afterward tells us that the "idea" of the play "is one that no circumstances can frustrate"(178).

As shown above, Jim, throughout the first three books, employs various interpretive strategies to tell the story of Ántonia and what she comes to mean to him. And yet, Jim's readings are fraught with inconsistencies and contradictions. For example, Jim as well as the Burden family read Ántonia's "manly behavior" as unacceptable, and yet it is this same spirit that urges her to cross gender lines that also makes her so attractive. Through Jim's inconsistent interpretations of Ántonia, fragments of a different picture begin to emerge, bits that can be read between the lines to form another view that we as readers may construct. In the last three books of the novel, the ironies present in Jim's perspectives are brought to the foreground through the rapid deconstruction of interpretive strategies he attempts to utilize. Ántonia, as already shown, doesn't neatly fit into certain categories of description; the conventional readings applied by Jim don't adequately describe her experience. Ántonia's "story" is one that requires different methods of interpretation, methods Jim begins to recognize in Book IV and V, and methods that we as readers have been exposed to since Book I.

In Book IV, Jim's context has again changed significantly. Jim, having left Lincoln and completed two years of law school at Harvard, has come home to spend vacation with his grandparents in Black Hawk. While visiting his old friends the Harlings, he hears about "poor Ántonia"-her unfortunate seduction by the rogue Larry Donovan, his desertion, and the illegitimate child Tony is left alone to raise. Jim initially views Ántonia and 
her unfortunate circumstances according to societal prescriptions of success, specifically material success: "I could not forgive her for becoming an object of pity." Jim notes that two other Black Hawk girls "for whom people had always foretold trouble" have become very successful financially and socially and much respected in Black Hawk. Lena Lingard has become the leading dressmaker in Lincoln and Tiny Soderball, after hitting it rich in the Klondike, returns to live on a considerable fortune in San Francisco, where Lena joins her. Ironically, Jim doesn't connect his own critique of Tiny's lifestyle to his views and standards concerning Ántonia. After briefly running into Tiny Soderball in Salt Lake City, Jim reports that Tiny "said frankly that nothing interested her much now but making money." Jim reflects: "She was satisfied with her success, but not elated. She was like someone in whom the faculty of becoming interested is worn out" (194). Although Jim observes that succeeding financially and socially does not ensure a meaningful existence, he doesn't connect this realization to his understanding of Ántonia.

In Book IV, Jim himself begins to question his interpretation of Ántonia after seeing the portrait of her daughter so prominately displayed in the local photographer's window. Clearly, Ántonia is not willing to accept the conventional reading of her situation, one that would view her life as over because of her "fall." Jim then determines to hear the actual story of her predicament and visits Widow Steavens, Ántonia's nearest neighbor. In "The Pioneer Woman's Story," Cather provides another voice to tell the account of Ántonia's failed relationship and the birth of her daughter. Cather moves Jim aside and lets another woman, Widow Steavens, tell the narrative with sympathy and understanding. Widow Steavens's story paints a picture 
of Ántonia we have come to know well-she unconventionally works "like a man" until the time of her child's birth, bears her child alone, and resolutely settles in to create a life for her new daughter. Widow Steavens's story serves to neutralize Jim's initial views of Ántonia's situation.

Jim resolves to meet with Ántonia the following day, and finds her shocking wheat in her family's field. Upon seeing Ántonia, Jim's disappointment and expectations for her are immediately dismantled by Ántonia's warmth, strength, and sincerity. Jim begins to see her qualities as mythic, almost archetypal. Applying the forms that he has come to learn from literature, he attempts to transform what is transient into something that is permanent, timeless. In the half-light of dusk Jim tells Ántonia that she is the bearer of the "closest, realest face" which he will see "under all the shadow's of women's faces" (207). And yet it should be noted that for us as readers, the outcome for Jim and Ántonia does not fit expected literary form; Jim and Ántonia do not "get together" to produce the "right ending."

Book $\mathrm{V}$, in many ways, repeats the pattern of Book IV, and yet Ántonia's presence comes through more strongly, in part because of Jim's apparent realization of the limitations of conventional modes of success. Jim delays fulfilling his promise to come back to see Ántonia for over twenty years, because he is again afraid she has not "done very well." Jim says he did not want to find her "aged and broken;" he doesn't want to lose his early "illusions" (211). But finally, Jim does take the initiative to stop off from one of his trips across the country to see his old friend. Similar to his experience with Ántonia almost twenty years now past, Jim finds that although Ántonia does not subscribe to the conventions for success-she has neither money, an 
independent career, or youthful looks-her existence is powerful and full of meaning, significance, and satisfaction.

Jim's description of his meeting with Ántonia is another illustration of the text's resistance to narrative conventions. Jim writes that before he could sit down in the chair Ántonia offers him, "the miracle happened; one of those quiet moments that clutch the heart, and take more courage than the noisy, excited passages in life" (213). Here Jim seems to affirm just the opposite of what takes place in a Jesse James tale, for example, a type of story he once found fascinating. Ántonia, grown older by twenty years, appears "battered." Although now a brown-skinned, flat-chested, woman with "grizzled" hair, Ántonia herself is not diminished: "As I confronted her, the changes grew less apparent to me, her identity stronger. She was there, in the full vigor of her personality" (214). And later Jim notes: "I know so many women who have kept all the things that she had lost, but whose inner glow has faded. ... Ántonia had not lost the fire of life. Her skin, so brown and hardened, had not that look of flabbiness, as if the sap beneath it had been secretly drawn away" (216).

As Jim comes to recognize, Ántonia is the center and author of a world filled with meaningful forms, relationships, and connections. Ántonia has created an abundance of life-literally. After showing Jim the cave which the family has stocked with jars of canned fruit and vegetables, her many children tumble out of the ground "all running up the steps together, big and little, towheads and gold heads, and brown, and flashing little naked legs; a veritable explosion of life out of the dark cave into the sunlight" (218). In addition to her large family, Ántonia has nurtured abundance in her natural surroundings. Jim and Ántonia visit her orchard where she strokes a tree 
and remarks "I love them as if they were people." Ántonia has created a thriving orchard on her farm where previously no trees had grown: "I couldn't get so tired that I wouldn't fret about these trees when there was a dry time. They were on my mind like children" (219).

Ántonia has not only created abundance literally, but also figuratively. She has fostered connection, caring, and pride between her many children. As Jim notices, they are proud of each other and of their number and share a "kind of physical harmony. They leaned this way and that, and were not afraid to touch each other." And perhaps most importantly, Ántonia infuses the world of the Cuzaks with stories. Stories permeate the fabric of her family's lives. Ántonia has told her children story after story of her own childhood, her parents, her relationship and experiences with Jim, the times with the Harling family. Frances Harling, for example, is said to have come down as a "heroine" in "the family legend" (225). In contrast to the stories Jim tells and uses to see the world around him such as The Life of Jesse James, Swiss Family Robinson, or Virgil's Georgics, Ántonia's stories are domestic tales, stories in which living people play the prominant roles. During Jim's visit, Ántonia and the children gather around a box of old photographs. The young Cuzaks huddle in close to see the pictures, contemplating them "with pleased recognition." They "looked at some admiringly, as if these characters in their mother's girlhood had been remarkable people" (224). The children know many of the stories we are familiar with from Book I and II-Otto's making of Mr. Shimerda's coffin, the rattlesnake Jim killed in the prairie dog town, the Harling family members-and yet they consistently ask for them to be told again and again $(225,231)$. Ántonia has even named some of her children in honor of past 
important characters in her life. Her daughter Nina, for example, is named after Nina Harling whom Ántonia took care of while she worked for the family.

Ántonia herself is an impetus for story telling. Jim writes that:

Ántonia had always been one to leave images in the mind that did not fade-that grew stronger with time. In my memory there was a succession of such pictures, fixed there like the old woodcuts of one's first primer: Ántonia kicking her bare legs against the sides of my pony when we came home in triumph with our snake; Ántonia in her black shawl and fur cap, as she stood by her father's grave in the snowstorm; Ántonia coming with with her work-team along the evening sky-line. ... She was a battered woman now, not a lovely girl; but she still had that something which fires the imagination (226).

Ántonia provides the spark for a very receptive and strong imagination in Jim. Similar to his reading in Book IV, Jim sees in Ántonia, the universal, the timeless. Jim writes: "She lent herself to immemorial human attitudes which we recognize by instinct as universal and true" (226). Ántonia appears to Jim as a "rich mine of life, like the founders of early races" (227).

Earlier in the novel, Jim has constructed interpretive structures as a way to make sense out of the vast expanse of the prairie and the hostile forces of nature. In the final book, Jim reads Ántonia for a surprisingly similar reason: to create meaning for the vast waste-land of his life. Jim has followed the conventional pattern for success; he has stuck to the recipe for recognition, supposed satisfaction, power and happiness. And yet, as the introduction notes, Jim's own marriage is a great disappointment and his career takes him all over the country, leaving him with no sense of place or home. Jim's modern existence is built on numerous structures, from societal conventions to educational forms, and yet these structures prove unable to provide any lasting meaning. In Ántonia's existence, Jim sees precisely what 
his own life lacks: permanent meaning. Throughout Book V, Jim attempts to read to Ántonia as myth, to make what is transient, contextual, grounded in familial contexts, into eternal truth. Significant in this last section is the tension between Jim's recognition of Ántonia's ability to generate a succession of images that lodge themselves in the mind, pictures that again defy containment by standard means of explanation, and his attempt to freeze them, to fix Ántonia's meaning into the broad category of the "universal."

By this last book, Jim and Ántonia have clearly reversed roles. From the outset Jim has been the story-teller, relating Ántonia's "story" often in terms of fictive, societal and rhetorical conventions. And, although Jim has followed the social prescriptions for success, he finds his own personal identity and significance to have faded. Ántonia, in contrast, stands at the center of "the family legend" to whom her children look for stories and meaning. In the final pages of the novel, Jim circles back to his initial experience on the prairie. Most, if not all, of his interpretational structures have collapsed and he takes comfort in the "incommunicable past"-a text which remains out of reach to interpretation.

As the previous pages illustrate, Jim spends five books remembering and associating in order to construct a reading of his past experience somehow symbolized within Ántonia. The novel is not about Ántonia per se, but about Jim's reading of Ántonia, her meaning for his own existence. Ántonia's "story" then, consists of the fragments left outside of Jim's interpretive templates, the narrative we as readers may construct as a result of 
Jim's competing and often contradictory perspectives. Throughout the text, we as readers are encouraged to see along with Jim through familiar strategies of explanation and interpretation, and at the same time are invited to see much more. We are asked to seek out the "the pattern that is supposed not to count in a story" (Bohlke 77). One such pattern that clearly emerges is of Ántonia resisting the interpretive structures imposed by Jim. Throughout the text we see Ántonia breaking with convention, which Jim and others frown on, but which we as readers register as fundamental to her personality. It is after all, Ántonia's fiery and independent nature, which makes her so memorable, likable, and strong; qualities that keep her from losing the "fire of life" and certainly "fire the imagination." Similarly, Ántonia's life at one point looks as if it will derail because of her affair with Donovan and the birth of her illegitimate child. But again, Ántonia refuses to "play the part," this time of the "fallen woman" and goes on to marry happily. And finally, Ántonia is repeatedly seen as not "having done very well"- unlike the other "hired girls" which become financial success stories. Instead, Ántonia remains a poor farmer and raises a large family, yet another choice which the other women in the novel shun. Ironically, it is Ántonia in the end that is able to author the most meaningful existence, an existence rich with imagination, resonate with the natural surroundings, and built on family connections. Ántonia's "story," through its pattern of resistance to conventional attempts at interpretation encourages a certain responsiveness on the part of the reader, an intellectual and emotional approach that does shut down meaning, but rather invites a consideration of the possibilities, an allowance for indeterminacy. 
Overall then, Cather has fashioned a text which dramatizes the human need to make sense of life-whether it be the inexplicable in nature, or the arbitrariness and artificiality that besets human quests for satisfaction. Cather's text clearly exposes, however, the fallibility of such conventional constructions of meaning. I would suggest that it is the presence of both processes-construction of meaning and its deconstruction, the presence of meaning and the gnawing feeling at the edges that really no meaning existsthat provides the emotional and intellectual complexity that makes this book so compelling. 


\section{- CHAPTER FOUR —}

\section{Connections}

In music, the term "invention" means the art of spinning something complex from a simple given line. The original baroque term for invention-Fortspinnung-suggests just this artistic license. An invention can be created from a simple foundation, such as a repeated bass pattern with melodies spun out above it. Or, an invention can take the form of a "puzzle," as seen in Bach's canons following the Goldberg Variations, where the annotations leave to the ingenuity of the musician (i.e., reader and performer) how the later lines imitate the earlier melody. Whether the later voices should be inverted, reversed, or begun at a different pitch is left ambiguous; the musician must construct his/her own interpretations based on the clues given through the feel, texture, and mood of the musical theme. As the English songwriter John Dowland wrote in 1609, the musician playing such a piece must "invent" his/her musical performance according to "an imaginarie rule, drawing on the part of the Song which is not set downe out of that part which is set downe. Or it is a Rule, which doth wittily discover the secret of a Song" (Runyon xi-xii).

This musical analogy perhaps provides a way of describing how Willa Cather's My Ántonia and Sarah Orne Jewett's The Country of the Pointed Firs work. Like a musical invention, Cather and Jewett's texts contain many voices played above a grounding baseline. The base "melody" in Jewett's work is really one of the daily separations of family, friends, and community through the forces of time, distance, and circumstance balanced by the 
reparations and friendships the community of Dunnet Landing seeks to maintain. The narrator, Elijah Tilley, Mrs. Todd, and Mrs. Blackett are voices that would connect, resonate, if you will, with one another in the reader's mind or ear.

In Cather's work, Ántonia occupies the base line, the center around which the other voices in the novel play-most prominently Jim Burden's, but also Mr. Shimerda's proud emphatic phrase "My Ántonia," Widow Steavens's, and even more softly the voice of Mrs. Harling. Cather's friend Elizabeth Shepley Sergeant remembers Cather voicing a similar framework for the novel, noting that: "this is something I remembered clearly when $M y$ Ántonia came into my hands." Sergeant recalls that Cather had "set an old apothecary jar of mine, filled with orange-brown flowers of scented stock, in the middle of a bare, round antique table" and said:

"I want my new heroine to be like this-like a rare object in the middle of a table, which one may examine from all sides."

She moved the lamp so that light streamed brightly down on my Taormina jar, with its glazed orange and blue design.

"I want her to stand out-like this-because she is the story" (Fryer 139).

As "performer/readers" of Jewett and Cather's works, we create the "harmony," or connections between the voices in these novels. According to the reader's own "imaginary rules" the voices in the text are emphasized variously, some play softer at times, others louder. We construct with the help from "that which is set downe" in the works the elements of which are not written down.

The above musical analogy helps highlight the similarities in the techniques used by Cather and Jewett. Briefly, both authors utilize a narrator fluent in the art of connection to assist in relating the experiences, each work 
invites the participation of the reader, and both Cather and Jewett avoid using a structure and plot that moves in a linear progression. Also important to note in more detail is Cather and Jewett's use of "embedded" narratives. Stories are spun off in seeming different directions from the main narrative. Cather and Jewett's texts record stories told incidentally in conversation, or from the lips of a sick person, or memories sparked by only a small eventare recorded with no overt purpose. And yet... In Jewett's case, the narrator often reads a larger significance from these small tales, as in the story of Joanna Todd. In many other cases, we are left to make our own connections, as in the case of the story related by Captain Littlepage of the shipwrecked crew who witnessed a far-away ghost island. In this instance, the narrator of the Firs gives little commentary about Littlepage's narrative, a habit much more common with the narrative style of Jim Burden. In Cather's text, many stories-such as the one told by the dying Russian immigrant in which a wolf pack chases down the bridal party, or the insect which reminds Ántonia of Old Hatta, a woman from the Shimerda's Bohemian homeland-provided without commentary or interpretation from the characters. Such stories and the way they are handled in Cather's work imply a certain narrative stance; they invite a method of interpretation which would actively utilize the emotions as well as the intellect, a certain appreciation rather than a quest to pin down precise meaning. This interpretational approach, I would argue, is practiced by the narrator and many other characters in Jewett's Firs, an idea I will return to.

The techniques Cather and Jewett utilize are of course also in many ways different. Jim Burden's narration would seemingly turn the story of Ántonia into "Jim Burden's Life." Burden repeatedly tries to read Ántonia 
and his past experiences according to a number of stock interpretational strategies, be they the road map for success that society outlines, conventional expectations regarding gender, story-book ideals for heroes and heroines, or finally the attempt to turn the mutable and the transient into the timelessness of myth. Ántonia, and the rich storied existence she surrounds herself with, never quite seems to stay inside the lines of Jim's interpretations. Like the numerous stories, observations, and even the plotline itself that elude explanation as well as our expectations for meaning, Ántonia resists conventional readings. She continually crosses gender lines, and chooses as a career farming and motherhood, the opposite of Jim Burden's choices. And in the end, Ántonia's existence proves the most rich and meaningful. Cather's form, a series of constructions built by Jim Burden, questions the very act of interpretation by clearly illustrating its limitations. The inherent critique in the text of Jim's interpretational strategies implies an invitation for different methods of reading than those he utilizes. Overall, Cather's narrative construction resists conventional expectations for closure and rewards a type of open reading and responsiveness that we can see practiced by many of the characters in Sarah Orne Jewett's Pointed Firs.

In Jewett's text, the narrator's approach to "reading" proves a sharp contrast to Jim's methodologies. Unlike Jim, who provides more details about his existence than Ántonia's, Jewett's narrator remains anonymous throughout the episodes-we never know her name, age, family background, and so on. Jewett's narrator does read situations and people, but her methods are not overt. She inquires, listens, records, responds in kind, and by definition shapes, but in an unobtrusive, almost invisible way. The narrator is apt illustration of the Romantic writer John Keats's definition of the poet- 
a figure that has no identity, because he/she is continually filling in some other point of view. Jewett's narrator exhibits this remarkable capability of being able to visualize another person's perspective. Furthermore, the narrator's capacity for connection knows no boundaries: the living, the deceased, and the unborn, and even her reading audience are all brought together into one community in the narrator's imagination, as are the "outsiders" of Dunnet Landing (Captain Littlepage and Joanna) made an integral part of its visible world.

Cather's techniques of narrative construction illustrate the limits of knowing and understanding through conventional ways of seeing. As mentioned in the introduction, the attempt to "report" in fiction, to portray reality as closely as possible, paradoxically reveals the futility of an objective point of view. Despite conventional wisdom, tried and true social structures, and so on, comprehending "reality" is ultimately a matter of construction, of making the best possible interpretation. Jewett's narrative techniques, in contrast, attempt to illustrate the possibility of collapsing individual perspective.

Finally, both Cather and Jewett point to what they see as the limitations of language as a tool for interpretation and connection. Cather's My Ántonia ends with Jim consoling himself over the lost years of friendship with Ántonia, but "whatever we had missed, we possessed together the precious, the incommunicable past" (Cather 238). Jewett's narrator similarly, on her fishing trip with William Blackett, admires his "fashion of life" with its silence and non-verbal communication. Clearly, both authors point to something beyond language, as has already been noted by Cather's preference for a quality in writing which creates a mood: "the inexplicable presence of 
the thing not named, of the overtone divined by the ear but not heard by it, the verbal mood, the emotional aura ... " (Cather 41-42). Jewett also noted in her diary a similar notion: "a story should be managed so that it should suggest interesting things to the reader instead of the author's doing all the thinking for him, and setting it before him in black and white" (Donovan 216). While this evocative approach used by both authors most certainly invites readers to participate in the creation of art, for the reader to envision and construct his or her own "invention," I would also argue that this method gives deference to the unknown, the inexplicable, the incommunicable. Cather and Jewett's texts invite a method of interpretation that doesn't pin down meaning, but rather a way of seeing that is comfortable with the unknown, the open-ended, the constantly changing. And by extension, such as way of seeing speaks to the concept of "knowing." For Cather and Jewett, "knowing" is cumulative process also furthered by the emotions as opposed to linear development and purely a function of the mind. Knowing Dunnet Landing, it inhabitants, its larger significance for the reader, is in part a matter of time, of seeing the characters such as Mrs. Todd from many different sides. Likewise, Ántonia, or what she comes to mean, is "known" by seeing her from many different angles, perspectives, contexts, and through many pairs of eyes including Jim's, Widow Steavens, and our own.

Clearly, seeing the texts as a dialogue of readers leads to a significantly different interpretation of Jewett's Pointed Firs and Cather's My Ántonia, than many critical readings outlined in the introduction. The critical method employed in this thesis does not look for how these two works fit given prescriptives, rather, it responds in kind to the texts and suggests possible 
descriptions. Such a critical approach doesn't try to "solve" the texts so much as it tries to see innovations and ruminate about their implications. 


\section{Chapter One}

1. To make this list I have relied on cataloging the assumptions made by feminist critics in the numerous articles read for this thesis as well as a description of a feminist approach offered by Elaine Showalter. In "Toward a Feminist Poetics" Showalter gives this description of an feminist critical approach: "Gynocritics begins at the point when we free ourselves from the linear absolutes of male literary history, stop trying to fit women between the lines of the male tradition, and focus instead on the newly visible world of female culture" (Showalter 1227).

2. My discussion is indebted to the following scholars and critical articles: Mikhail Bakhtin's "Epic and Novel: Toward a Methodology for the Study of the Novel," David Laird's "Willa Cather's Women: Gender, Place, and Narrativity in O Pioneers! and My Antonia," Richard Millington's "Willa Cather and 'The Storyteller': Hostility to the Novel in My Antonia," Susan Rosowski's "The Romanticism of My Antonia," and Marcia McClintock Folsom's "Tact is a Kind of Mind-Reading": Empathic Style in Sarah Orne Jewett's The Country of the Pointed Firs."

3. The critic John Hirsch, in "The Non-Narrative Structure of The Country of the Pointed Firs" argues a similar viewpoint. Hirsch believes that the first and last chapters of the work construct the frame, wherein the content alternates progressively between two types of events: "incidents which describe ... the Todd family, and incidents concerned with outsiders (Hirsch 286). Hirsch goes so far as to outline in table format the identical number of chapters Jewett has allotted to occurrences which concern "outsiders" and "insiders" of the Todd family.

4. Paul Volker also expresses a similar view. Volker's study "The Country of the Pointed Firs: A Novel by Sarah Orne Jewett," follows the narrator chapter by chapter in order to show her growth as part of a "progressive chain."

5. While Subbaraman's analysis makes a significant addition to the discussion of Jewett's form, for he perceives the burden the text places on readers for reconstruction, his understanding still leans heavily on a linear progression, an assumption common to each of the arguments briefly covered in the previous text.

6. In fact, modernist male writers including James Joyce, John Dos Passos, and William Faulkner made significant experiments with stream of conscious techniques, collage, and multiple narrators, all of which could be described as "circular" in nature.

7. For more feminist approaches to the Firs that focus on the depiction of women see Jennifer Bailey and Josephine Donovan. In her article "Female Nature and the Nature of the Female: a Re-vision of Sarah Orne Jewett's The Country of the Pointed Firs," Bailey assures that the Firs will not "be assimilated all too easily into a male-centered literary tradition" (Bailey 283). 
Bailey argues that Jewett's coastal setting reads symbolically in order to portray a female version of nature and similarly an illustration of the "nature of the female." For Bailey, the country of the pointed firs "with its landscape of curves and sweeps through cultivated pasture to distant horizons is, therefore, a female kingdom" (291). Similarly, Josephine Donovan argues that Jewett's later works such as the Firs "point in the direction of a woman's religion of healing, hospitality and community" (Donovan 380). Mary Roman however, would disagree with the views outlined above. For Roman, in Sarah Orne Jewett: Reconstructing Gender, the Firs does not support the interpretation of Dunnet Landing as a "female kingdom," instead it is a place "wherein the allocation of gender roles is called into question" (Roman 207).

8. David Stouck, for example, returns to the classical form of the pastoral to provide a shape for his reading. In his article "My Antonia as Pastoral," Stouck suggests that the work's structure is informed by the central paradox of the pastoral genre, the "tension between the memory of former happiness and the reality of loss and estrangement in the present" (Stouck 55). According to Stouck, viewing the novel as a pastoral accounts for Jim's presence and his apparently random recollections, for Jim is remembering a "golden age" of sorts, and only through the narrator can we feel nostalgia and the incredible distance between the gloomy present and the glorious past. For other arguments which might be considered as using the "abstraction" approach see Terance Martin in "The Drama of Memory in My Antonia," and Joseph Murphy's "My Ántonia as Plains Epic."

9. See also the argument of James Miller, Jr. in "My Antonia and the American Dream."

10. And still other critics turn to arguments very similar to those scholars trying to find unity in Jewett's work, citing the growth of Jim Burden, the narrator of My Antonia, as the key to assumed coherence. John Selzer, for example, argues that the piece is "hardly formless." Rather, the narrator's "moral awakening enables him to shape each part .... My Antonia is tightly structured in a way that dramatizes the events of Ántonia's life and her final triumph, that critiques the errors in Jim's life, and that sanctions his final comprehension of those errors" (Selzer 59).

11. The groundwork for Lambert and Fetterly's interpretation was laid by Sharon O'Brien, who, in her article "'The Thing Not Named': Willa Cather as a Lesbian Writer" and her autobiography of Cather, establishes a portrait of Cather as a lesbian author. In addition to drawing on biographical data, O'Brien interprets a statement penned by Cather in her essay "The Novel Démeublé" as evidence of the close connection between Cather's homosexuality and her literary work. Cather wrote:

Whatever is felt upon the page without being specifically named there-that, one might say, is created. It is the inexplicable presence of the thing not named, of the overtone divined by the ear but not heard by it, the verbal mood, the emotional aura of the fact or the thing or the deed, that gives high quality to the novel or the drama, as well as to poetry itself (emphasis mine, O'Brien 576).

For O'Brien, the "thing(s) not named" and yet significantly present, are the emotional bonds between women that were central to Cather's life. O'Brien argues that this passage from Cather shows her dilemma as a "lesbian writer forced to disguise or to conceal the emotional source of her fiction" (O'Brien 577). Several other feminist critics have built their O'Brien's 
conclusions, including Josephine Donovan in "The Place of My Antonia in Women's Literary Traditions," Patrick Shaw in "My Ántonia: Emergence and Authorial Revelations," and Elizabeth Ammons in Conflicting Stories .

12. Blanche Gelfant in "The Forgotten Reaping-Hook: Sex in My Antonia" also constructs an argument along similar lines. 


\section{Chapter Two}

1. Only one comment referring to Jewett's wishes exists in a letter written by Mary Jewett. Following the release of the 1909 edition, Mary Jewett wrote an editor at Houghton Mifflin noting:

The Pointed Firs in its new dress has this hour come to my hand, and I hasten to thank you for it, and tell you how much I like it in every way. It was a surprise and pleasure when I found the Queen's Twin added to he original book as my sister always hoped it might be sometime.

(Portales 587).

2. Naturally, critics have weighed in on both sides of the definitive edition issue. The early critic W. Berthoff decided to work with the original 1896 edition, believing it was the "proper text" since it was the only one authorized by Jewett herself. Alternatively, Francis Fike argued for Cather's 1925 edition on the grounds that Jewett "implied the desirability of the addition by using the term 'chapter,' but also by continuing to focus on the same central characters through the same narrator." (Portales 590). David Bonnell Green agrees, arguing that the sketches are "vital parts of the world of Dunnet Landing." Most recently however, critics including Marjorie Pryse have returned to a position similar to that of Berthoff's stance, insisting that scholars must follow the author's intention to the best of their knowledge. Marco Portales points out that the sketches in question are most certainly "related" to the original text, but being "related" is different from them being included within the original (Portales 598). 
Ammons, Elizabeth. "Going in Circles: The Female Geography of Jewett's Country of the Pointed Firs." Studies in Literary Imagination 16 (1983): 83-92.

Bailey, Jennifer. "Female Nature and the Nature of the Female." Revue Française d'Études Americaines. 8 (1983): 283-294.

Bahktin, Mikhail. "Epic and Novel: Toward a Methodology for the Study of the Novel." In Critical Theory Since Plato. Ed. Hazard Adams. New York: Harcourt Brace Jovanovich, 1992. 838-856.

Berthoff, Warner. "The Art of Jewett's Pointed Firs." In The World of Dunnet Landing. Lincoln: University of Nebraska Press, 1962.

Bohlke, L. Brent, ed. Willa Cather in Person. Lincoln: University of Nebraska Press, 1986.

Carson, Richard. "Nature and the Circles of Initiation in The Country of the Pointed Firs." The Colby Library Quarterly 21 (1985): 154-160.

Cather, Willa. My Ántonia. Boston: Houghton Mifflin Company, 1988.

Daiches, David. "Decline of the West." In Modern Critical Interpretations: Willa Cather's My Ántonia. Ed. Harold Bloom. New York: Chelsea House Publishers, 1987. 7-19.

Donovan, Josephine. "The Place of My Ántonia in Women's Literary Traditions." In Approaches to Teaching My Ántonia. New York: Modern Language Association of America, 1989. 71-76. 
"A Woman's Vision of Transcendence: A New Interpretation of the Works of Sarah Orne Jewett." The Massachusetts Review 21 (Summer 1980): 365-380.

Durso, Patricia Keefe. "Jewett's 'Pointed Firs': An 'Index Finger' to Character Development and Unity of Vision in The Country of the Pointed Firs." The Colby Library Quarterly 26 (1990): 171-181.

Fetterly, Judith. "My Ántonia, Jim Burden and the Dilemma of the Lesbian Writer." In Gender Studies: New Directions in Feminist Criticism. Bowling Green: Bowling Green State University Popular Press, 1986. 43-59.

Folsom, Marcia McClintock. "'Tact is a Kind of Mind-Reading'": Empathic Style in Sarah Orne Jewett's The Country of the Pointed Firs." Colby Library Quarterly 18 (1982): 66-78.

Fryer, Judith. Felicitous Space: The Imaginative Structures of Edith Wharton and Willa Cather. Chapel Hill: University of North Carolina Press, 1986.

Gelfant, Blanche. "The Forgotten Reaping-Hook: Sex in My Ántonia." American Literature 43 (1971): 60-82.

Hirsch, John C. "The Non-Narrative Structure of The Country of the Pointed Firs." American Literary Realism, 1870-1910 14 (1981): 286-288.

Jewett, Sarah Orne. The Country of the Pointed Firs. New York: W.W. Norton and Company, 1981. 
Laird, David. "Willa Cather's Women: Gender, Place, and Narrativity in O Pioneers! and My Ántonia." Great Plains Quarterly 4 (1992):242-53.

Lambert, Deborah. "The Defeat of a Hero: Autonomy and Sexuality in My Ántonia." American Literature 53 (1982): 676-690.

Lee, Hermione. "The Road of Destiny." In Willa Cather: A Life Saved Up. London: Virago Press, 1989. 133-158.

Martin, Terence. "The Drama of Memory in My Antonia." In Modern Critical Interpretations: Willa Cather's My Ántonia. Ed. Harold Bloom. New York: Chelsea House Publishers, 1987. 51-65.

Miller, James Jr. "My Ántonia and the American Dream." Prairie Schooner 38 (1974): 48-52.

Millington, Richard. "Willa Cather and 'The Storyteller': Hostility to the Novel in My Ántonia. Unpublished essay, 1994.

Murphy, Joseph. "Cather's Re-Vision of American Typology in My Antonia." In Modern Critical Interpretations: Willa Cather's My Ántonia. Ed. Harold Bloom. New York: Chelsea House Publishers, 1987. 213-219.

O'Brien, Sharon. "'The Thing Not Named': Willa Cather as a Lesbian Writer." Signs 9 (1984): 576-600.

Portales, Marco. "History of a Text: Jewett's The Country of the Pointed Firs." The New England Quarterly 55 (1982): 586-592.

Randall III, John H. "The World of Nature" In Ántonia. Ed. Harold Bloom. New York: Chelsea House Publishers, 1991. 65-81.

Roman, Margaret. "Beyond Gender: The Country of the Pointed Firs." In Sarah Orne Jewett: Reconstructing Gender, 1992. 207-230. 
Rosowski, Susan. "My Ántonia: The Closing of the Circle." In The Voyage Perilous: Willa Cather's Romanticism, 1986. 75-91.

"The Romanticism of My Ántonia: Every Reader's Story." In Approaches to Teaching My Ántonia. New York: Modern Language Association of America, 1989. 64--70.

Runyon, Randolph. Fowles/Irving/Barthes: Canonical Variations of an Apocryphal Theme. Columbus: Ohio State Uniersity Press, 1981. xi-xii.

Saposnik-Noire, Shelley. "The Silent Protagonist: The Unifying Presence of Landscape in Willa Cather's My Ántonia." The Midwest Quarterly 31 (1990):171-179.

Selzer, John. "Jim Burden and the Structure of My Ántonia." Western American Literature 24 (1989): 45-63.

Shaw, Patrick. "My Ántonia: Emergence and Authorial Revelations" American Literature 56 (1984): 527-40.

Showalter, Elaine. "Towards a Feminist Poetics." In Critical Theory Since Plato. Ed. Hazard Adams. New York: Harcourt Brace Jovanovich, 1992. 1223-1234.

Sternshein, Mary Kemper. "The Land of Nebraska and Antonia Shimerda." Heritage of the Great Plains. 16 (1983): 34-42.

Stouck, David. "Perpective as Structure and Theme in My Ántonia." In Modern Critical Interpretations: Willa Cather's My Ántonia. Ed. Harold Bloom. New York: Chelsea House Publishers, 1987. 67-77.

- . "My Ántonia as Pastoral." In Approaches to Teaching My Ántonia. New York: Modern Language Association of America, 1989. 53-57. 
Stuckey, William. "My Ántonia: A Rose for Miss Cather." Studies in the Novel 4 (1972): 473-83.

Subbaraman, Sivagami. "Rites of Passage: Narratorial Plurality as Structure in Jewett's The Country of the Pointed Firs." The Centennial Review 33 (1989): 60-74.

Waggoner, Hyatt. "The Unity of The Country of the Pointed Firs." In The World of Dunet Landing. Lincoln: University of Nebraska Press, 1962. 